\title{
Governance Through Trading: Does institutional trading discipline empire building and earnings management?
}

\author{
Eric C. Chang ${ }^{\mathrm{a} *}$ Tse-Chun Lin ${ }^{\mathrm{a} \dagger}$ Xiaorong Ma ${ }^{\mathrm{a}} \uparrow$ \\ ${ }^{a}$ University of Hong Kong
}

\begin{abstract}
This paper empirically identifies an important external corporate governance mechanism through which the institutional trading improves firm values and disciplines managers from conducting value-destroying behaviors. We propose a reward-punishment intensity (RPI) measure based on institutional investors' absolute position changes, and find it is positively associated with firm's future risk-adjusted returns and Tobin's Q. Importantly, we find that firms with higher RPI exhibit less subsequent empire building and earnings management. Our results suggest that the improved firm values can be attributed to the discipline effect of institutional trading on managers, which is in line with the argument of "Governance Through Trading". Furthermore, we find that the exogenous liquidity shock of decimalization augments the governance effect of institutional trading. We also find that the discipline effect is more pronounced for firms with lower institutional ownership concentration, higher stock liquidity, and higher managers' wealth-performance sensitivity, which further supports the governance role of the RPI.
\end{abstract}

JEL classification: G20, G30, G32.

Keywords: governance through trading, institutional trading, stock returns, empire building, earnings management

We have benefited from the comments of Geert Bekaert, Sreedhar Bharath, Dion Bongaerts, Ling Cen, Lauren H. Cohen, Joost Driessen, Jiekun Huang, Paul Hsu, Micah Officer, Kelsey D. Wei, Hong Zhang. We gratefully acknowledge the research support from the Faculty of Business and Economics at the University of Hong Kong and the Research Grant Council of the Hong Kong SAR government. Any remaining errors are ours.

${ }^{*}$ Faculty of Business and Economics, Tel.: +852-2219-4567. E-mail address: ecchang@hku.hk

${ }^{\dagger}$ Corresponding Author. Faculty of Business and Economics, Tel.: +852-2857-8503. E-mail address: tsechunlin@hku.hk

${ }^{\ddagger}$ Faculty of Business and Economics, Tel.: +852-6841-4405. E-mail address: xrma@hku.hk 


\section{Introduction}

What do institutional investors do when they are dissatisfied with corporate performance? Earlier studies suggest that institutional investors may directly intervene and voice in the board or shareholder meetings. Recently, several theoretical works promote the idea, "Governance Through Trading", which disciplines managerial behavior and enhances firm value via institutional trading (Admati and Pfleiderer (2009), Edmans (2009), and Edmans and Manso (2011)). McCahery, Starks, and Sautner (2010) provide survey evidence that institutional investors prepare to employ "Selling Shares" as a primary governance mechanism. ${ }^{1}$ Bharath, Jayaraman, and Nagar (2012) find that the threat of exit from blockholders could discipline the mangers and enhance Tobin's Q. Edmans, Fang, and Zur (2013) show that both likelihood of a hedge fund filling Schedule 13Gs (passive investments) and announcement returns of the filers increase with liquidity. While the evidence in the previous two empirical studies helps to understand how liquidity improves the effectiveness of "Governance Through Trading", our paper contributes to the literature by identifying the channels through which firm values would increase. Specifically, we propose a reward-punishment intensity (RPI) measure based on institutional investors' absolute position changes and investigate whether firms with higher RPI have higher values via lower managerial tendency of empire building and earnings management.

The literature has shown that institutional investors act proactively to gather information concerning firms' fundamental values. If managers engage in value-destroying behaviors, which are detected subsequently, institutional investors could express their objection by selling the shares. ${ }^{2}$ Stock prices would be thus pulled down accordingly. On the contrary, if managers work hard and undertake actions enhancing firm values, institutional investors would buy more shares, which boosts stock prices. In this regard, institutional trading serves as a discipline force to punish and reward managers as long as their compensation is linked to stock prices. The intensity of this reward-punishment force manifests the ability and the willingness of the institutional investors' "Governance Through Trading". Hence, we argue that the reward-punishment intensity, reflected

\footnotetext{
${ }^{1}$ McCahery et al. (2010) conduct a survey and find that around 80\% (most popular) of responding institutional investors will sell their shares of firms with misbehavior.

${ }^{2}$ Literature suggests that institutional investors might take activism directly as well. However, empirical studies provide mixed evidence regarding whether institutions enhance firm value through direct intervention (Woidtke (2002), Gillan and Starks (2000), Klein and Zur (2011), and Klein and Zur (2009)).
} 
by institutional investors' absolute position changes, imposes a valid external governance mechanism on managers by stating that the firms are monitored by observant investors. Any detected managerial misbehavior by the institutional investors could lead to severe punishments by dumping the shares. Managers would thus be more well-behaved ex ante, and it leads to a higher firm value ex post. Therefore, we propose our first hypothesis that higher reward-punishment intensity (RPI) would result in higher subsequent firm values due to less value-destroying managerial activities.

Next, we investigate whether the value of the firm is increased because the value-destroying activities, in the forms of empire building and earnings management, are mitigated by the discipline force of RPI. Managers have incentives to build up empires to enjoy private benefits at the expense of shareholders' interests. ${ }^{3}$ The empire building behavior would be reflected in increased abnormal capital investment and results in lower subsequent firm values (Titman et al. (2004)). Moreover, managers also have incentives to distort reported financial information to boost their compensations, gain benefits from insider trading, or secure their jobs, and such distortions can harm firm value as well. ${ }^{4}$ The discipline force brought by the RPI, as illustrated in our first hypothesis, could deter managers from over-investing and distorting financial information. ${ }^{5}$ This would in turn improve firm future values. We therefore propose our second hypothesis that the link between the RPI and firm subsequent value is attributable to the discipline force of institutional trading, which mitigates the managers' tendency to build up empires and manage earnings.

The intuition of the RPI is from Edmans and Manso (2011), who state that "Instead, "too much" trading is beneficial for firm value as it increases price informativeness and induces (managerial) effort ex ante." The implication is that information-driven trading by institutional investors is in itself a disciplining mechanism. Thus, we construct the RPI for a firm in a certain year as the absolute quarterly change in portfolio holding of an institutional investor, and then the absolute change is aggregated across all institutional investors who hold the stock and over the four quarters. ${ }^{6}$ The RPI is essentially a noisy measure for the amount of institutional trading in one year as we use four snapshots of quarterly institutional holding data for the construction. However, it could

\footnotetext{
${ }^{3}$ See Jensen (1986), Titman, Wei, and Xie (2004), and Billett, Garfinkel, and Jiang (2011).

${ }^{4}$ See Ahmed, Zhou, and Lobo (2006), Bergstresser and Philippon (2006), Cornett, Marcus, and Tehranian (2008), Karpoff, Scott Lee, and Martin (2008), and Karpoff and Lou (2010).

${ }^{5}$ In this paper, we will use the term over-investment and empire building as interchangeable.

${ }^{6}$ See Section 3.2 for a detailed discussion.
} 
still largely reflect the real capacity of "Governance Through Trading" from institutional investors, which represents the reward-punishment intensity that managers face in the subsequent year.

It is important to note that we employ the absolute position changes rather than signed ones, since it takes both the foreseeable reward (institutional buy) and the punishment (institutional sell) to incentivize managers to perform and to discipline them from misbehaving. The pure threat to exit as a governance mechanism may work ex ante. However, if the exit has taken place, managers could perform better or worse depending on whether their subsequent performance would be able to earn back those investors who left or attract new investors. Hence, we do not only consider the case when institutional investors sell their shares and exit. We combine sells and buys together, and use the absolute value of the institutional investors' position changes to capture the discipline effect stemmed from institutional trading. In a nutshell, the higher the RPI, the higher the discipline force managers are facing.

One alternative hypothesis that could potentially account for the positive correlation between institutional trading and firm value is that the association between RPI and subsequent firm value and managerial behavior may be purely driven by the positive private information held by institutional investors. If some institutional investors happen to know that the manager will not conduct empire building or earnings management in the coming year, they might increase their equity position of the firm, which could also result in the positive relation between the lagged RPI and firm value. However, this concern would be alleviated if the reduction in institutional investor equity positions also leads to improvement of firm values.

In addition, one might be concerned that more institutional trading results in higher firm value as the level of institutional ownership is positively related both to trading and to firm value (Gompers and Metrick (2001)). In order to rule out this possible explanation, we would include institutional ownership ratio in our regression, and examine whether the effect of institutional trading on firm value still holds.

To test the first hypothesis, we use a panel data of U.S. stocks over 1980 to 2011 . We find that stocks with high RPI in the previous year earn significantly higher risk-adjusted returns than stocks with low RPI. In particular, a portfolio constructed by longing stocks in the highest decile of the 
RPI and shorting stocks in the lowest decile of the RPI generates monthly alpha of $0.66 \%$ in the subsequent year after adjusting for Fama and French (1993) three factors, Carhart (1997) momentum factor, and the Pastor and Stambaugh (2003) liquidity factor. Using Fama and MacBeth (1973) methodology and Petersen (2009) two-way clustered standard errors panel regression, we also find a strong and positive relationship between the RPI and the subsequent stock returns, by controlling for total accrual, sales growth, dividend yield, asset growth, past stock returns, and institutional ownership ratio. ${ }^{7}$ In addition, consistent with Bharath et al. (2012), our results show that the firm Tobin's Q is positively associated with the past RPI. Collectively, we provide comprehensive evidence to support our first hypothesis that the firm value increases with higher RPI in the previous year.

Next, we move to test whether the improved firm value is owing to the governance effect of institutional trading on agency problems, by examining the relationship between the lagged RPI and the managers' tendency to engage in empire building and earnings management. Specifically, we employ two methods to gauge the extent to which managers tend to build up their empires. First, following Whited (2006), we use a hazard model which captures the frequency of large investments (spikes) and the time between two adjacent investment spikes (spells). The advantage of the hazard model is that it addresses both the issue of measurement errors in instruments for investment opportunities (Tobin's Q) and the lumpy feature of corporate investments. Our results suggest that managers at firms with high lagged RPI will have low propensity to overinvest, which is reflected by the low hazard rate and long spells between two investment spikes. Specifically, we find that given that the firm's investment rate does not exceed two times the firm median investment rate at year $t$-1, a one-standard-deviation increase in RPI leads to $9.45 \%$ decrease in the hazard rate of over-investment. ${ }^{8}$ Billett et al. (2011) use the same hazard estimation and find the propensity of the firm managers to over-investment is lower for firms with better corporate governance (Low G-Index). Hence, we control for two proxies for the effectiveness of corporate governance provisions (G-index introduced in Gompers, Ishii, and Metrick (2003) and E-index introduced in Bebchuk,

\footnotetext{
${ }^{7}$ Given that the RPI might capture the pattern of institutional investors' systematic strategies, such as momentum, we also include past stock returns to rule out this potential effect.

${ }^{8}$ In this case, we regard the two times of the firm median investment rate as the benchmark of over-investment. We also examine other benchmark for over-investment, including 2.5 times and 3 times of the firm median investment rate.
} 
Cohen, and Ferrell (2009)), and find our results still hold. Second, we use the abnormal capital investment (CI), introduced in Titman et al. (2004), as an alternative way to gauge the tendency of empire building. We find that a one-standard-deviation increase RPI results in 0.14 standard deviation decrease in abnormal capital investment, suggesting that intensive institutional trading would discourage managers from making over-investment.

We employ the performance-matched discretionary accrual measure to examine whether the RPI could discipline managers from manipulating the earnings report. Specifically, following Hazarika, Karpoff, and Nahata (2012), we use the absolute value of discretionary accrual, as the discretionary accruals could be used to both increase and decrease the reported earnings. On the one hand, managers, who attempt to bolster their compensation and to issue new equity, have incentives to inflate the reported earnings. ${ }^{9}$ On the other hand, ill-motivated managers would deflate reported earnings, before the reissue of options or before the repurchase of shares. ${ }^{10}$ Thus, we use the absolute value of the performance-augmented discretionary accrual to capture the managers' earnings management in both direction. Our results show that the lagged RPI is negatively associated with the absolute value of the performance-augmented discretionary accrual in the following year, indicating that the discipline effect of institutional trading would dampen managers' incentives to manipulate reported earnings in both directions.

To further support that the results are consistent with the implication of "Governance Through Trading", we explore the interaction effects of the RPI and factors that are known to have governance effects. We investigate to what extent these governance factors would complement or substitute the discipline effect of the RPI on the managers' misbehaviors, such that the documented impact of lagged RPI on the two agency problems can be attributed to the governance mechanism. Specifically, we focus on positive liquidity shock of decimalization (Decimal), the institutional ownership concentration (IOC), the Amihud's (2002) illiquidity measure (ILLIQ), the Edmans, Gabaix, and Landier's (2009) scaled wealth-performance sensitivity (WPS), and the Kaplan and Zingales's (1997) Kaplan-Zingales Index (KZ index) for the degree of financial constraint.

First, we investigate whether stock liquidity enhances the discipline effect of the RPI. Both

\footnotetext{
${ }^{9}$ See also Teoh, Welch, and Wong (1998), Burns and Kedia (2006), and Efendi, Srivastava, and Swanson (2007).

${ }^{10}$ See also Coles, Hertzel, and Kalpathy (2006) and Gong, Louis, and Sun (2008).
} 
Bharath et al. (2012) and Edmans et al. (2013) document that exogenous positive liquidity shock of Decimalization and high stock liquidity (low Amihud (2002) ILLIQ) reinforce exit threats, and then improve firm values. Following these two papers, we also use decimalization and ILLIQ and argue that the discipline effect of the RPI will be complemented by a higher level of overall trading liquidity. Our result shows that liquidity and institutional trading are complements in mitigating the subsequent agency problems, and thus the high trading liquidity would improve the effectiveness of "Governance Through Trading".

Second, the institutional ownership concentration is employed to address the interaction between free-rider problem of institutional activism and the "Governance Through Trading". Edmans and Manso (2011) imply that a low institutional ownership concentration will generate the free-rider problem by hindering the direct intervention, as the active investors take all the costs, whereas the benefits accrue to all shareholders. However, the same free-rider issue in the low IOC firms will strengthen the another form of governance, "Governance Through Trading", because the trading among investors will be easier. Therefore, we should expect to see a more pronounced RPI effect for firms with low institutional ownership concentration. Indeed, we find that the coefficient on the interaction term between the RPI and the IOC is positive and significant, suggesting that a lower level of institutional ownership concentration would enhance the governance mechanism via institutional trading.

Third, "Governance Through Trading" suggests that the effectiveness of the discipline effect stems from the sensitivity of managers' wealth to stock price (Admati and Pfleiderer (2009), Edmans (2009), and Edmans and Manso (2011)). The discipline effect of the RPI on agency problems should therefore be stronger for firms whose managers' wealth is more sensitive to the firm performance. Following Edmans et al. (2009), we employ the scaled wealth-performance sensitivity (WPS) to gauge the extent to which the firm manager's wealth is related to stock price. We find negatively significant coefficient on the interaction term between the RPI and the WPS, lending support to our interpretation that the negative association between RPI and the agency problems is owing to the governance mechanism.

Finally, we examine how the KZ index of financial constraints affects the discipline effect in the context of empire building. Whited (2006) argues that financial constraints might incur additional 
costs of adjusting the capital, and then delay the time between two large investments. Billett et al. (2011) find that in the presence of financial constraints, there are no effect of corporate governance provision (G-Index) on the managerial empire building behavior, suggesting that the corporate governance provision and financial constraints are substitutes in alleviating the agency problems. Thus, we expect that the discipline effect of RPI on empire building is more likely to be found in firms with less financial constraints. We find positively significant coefficient of the interaction between the RPI and the KZ index, suggesting that intensive institutional trading exhibits stronger corporate governance effect in financial unconstrained firms, consistent with the findings in Billett et al. (2011).

In sum, our findings that the discipline effect of RPI on empire building and earnings management is more pronounced for firms with high liquidity, low institutional ownership concentration, high wealth-performance sensitivity, and low financial constraints further substantiate our second hypothesis that the positive relation between the institutional trading and firm future values is through the discipline effect on the two agency problems.

To shed light on the alternative hypothesis, we divide our sample firms into two groups based on the annual changes in aggregate institutional ownership ratio, and examine whether our main results remain in the subsample with the changes in institutional ownership below the median. Indeed, we find that our main results are qualitatively similar in this subsample, which suggests that the association between institutional trading and firm value is not purely driven by the positive information held by invitational investors.

To further address the endogeneity concern, we employ the mean RPIs of all firms (excluding firm $i$ 's own RPI value,) in the same state, same year, and same industry, RPI_SYI(- $i$ ), as our instrumental variable for the RPI, in the same spirit of Kim and $\mathrm{Lu}$ (2011). The idea is that some institutional investors might aim at firms with similar location and industry. Then, RPI_SYI(- $i$ ) may be associated with firm $i$ 's RPI, while peer firms' RPI may not directly affect firm $i$ 's managerial behavior. Using RPI_SYI(- $i$ ) as instrumental variable, we find consistent results.

The remainder of the paper proceeds as follows. Section 2 reviews the relevant literature. Section 3 describes the data and the measure of RPI. Section 4 discusses the empirical results, 
Section 5 presents additional supporting evidence, Section 6 includes robustness checks, and Section 7 concludes.

\section{Literature Review}

\subsection{Governance Through Trading}

When investors are dissatisfied with some aspects of firms' management or operations, they might simply sell their shares, also know as "Vote with Feet" or "Wall Street Rules". Lowenstein (1989) states that "[Institutional Investors] implicitly praise or criticize management, by buying or selling, but seldom get involved more directly, even to the extent of a phone call. There is almost no dissent from the Wall Street Rule....". Gillan and Starks (2007, pp.56) argue that "At one end, we could view shareholders who simply trade a company's shares as being "active." Through their initial purchases and subsequent decisions to hold or sell, shareholders are expressing their views of the corporation's performance." Further, McCahery et al. (2010) conduct a survey and find that around $80 \%$ of responding institutional investors are willing to employ "Wall Street Rule" as a governance mechanism.

On the theoretical side of the literature, Edmans (2009) provides a model based on a large informed blockholder, who could trade on information and then encourage mangers to undertake activities in firm's long-run growth instead of short-term profits. The model also explains the popularity of small transient blockholders in the United States. Those investors could improve firm values by "Voting with Feet" even if they hardly intervene firm's operation directly. ${ }^{11}$ Likewise, Admati and Pfleiderer (2009) analyze a model of a single large shareholder with exogenous information. It shows that the large shareholder does not undertake costly intervention or "shareholder activism", yet engage in trading on her information, which might then affect managers' decisions. Edmans and Manso (2011) argue that the free-rider problems, which may dampen the shareholders' incentive to intervene, cause another form of discipline force, "Governance Through Trading", to be strengthened. By splitting shares among multiple blockholders, Edmans and Manso (2011) show that trading volume and subsequent firm value will increase. On the empirical side, Bharath et al. (2012) employ three natural liquidity shocks, namely Decimalization, Russian, and Asian crises,

\footnotetext{
${ }^{11}$ See also Gaspar, Massa, and Matos (2005) and Bushee (1998).
} 
and show that the ability of blockholder to "selling their shares" is an effective governance force. Edmans et al. (2013) show that the 13Gs (passive investments) filing of liquid firm will result in a positive announcement return. This provides evidence that liquidity increases the propensity of hedge funds to file Schedule 13Gs (passive investments) instead of 13Ds (active investments) and positive market reaction, indicating that liquidity encourages blockholders to govern through trading. ${ }^{12}$

Our paper contributes to and complements this new strand of the literature in the following ways. First, we propose the reward-punishment intensity (RPI) measure to gauge the extent to which mangers are disciplined by the "Governance Though Trading." Second, we provide comprehensive evidence that the "Governance Though Trading" is positively associated with future risk-adjusted returns, returns accounted for known asset pricing anomalies, and firm Tobin's Q while the existing studies mainly focus on the last one. Last and foremost, we identify two channels, empire building and earnings management, through which the agency problems (managerial value-destroying behavior) are mitigated by the discipline force of the RPI.

\subsection{Empire Building and Earnings Management}

Jensen (1986) states that "Mangers have incentives to cause their firms to grow beyond the optimal size. Growth increases managers' power by increasing the resources under their control." This type of managerial behavior is based on power play and manager's ego, which will then cause harm to shareholder. Whited (2006) develops an empirical methodology based on hazard estimation to examine the managerial over-investment behavior. Hazard estimation investigates the "hazard rate" rather than the level of investment, and thus avoids the computation of the proxy for investment opportunities. ${ }^{13}$ This method also allows for the lumpy feature of corporate investment, by focusing on the time that passes since firms' last large investment.

Following Whited (2006), Billett et al. (2011) opt for the hazard estimation approach, and

\footnotetext{
${ }^{12}$ Using Australian data, Gallagher, Gardner, and Swan (2012) find that short-horizon swing trades of multiple institutional investors will improve price informativeness and thus increase the subsequent firm performance. It suggests that institutional trading could effectively discipline corporate management. Chen and Swan (2012) argue that managers' equity-based compensation and informed institutional trading are substitutes, indicating the monitoring role of institutional investors based on "Wall Street Rules".

${ }^{13}$ Regarding the measurement errors in Tobin's Q, please refer to Erickson and Whited (2000), Cooper and Haltiwanger (2006), and Cummins, Hassett, and Oliner (2006)
} 
examine the effect of corporate governance provisions, proxied by Gompers et al. (2003) G-Index, on the timing of large investment. Their results show that firms with good governance present longer time between investment spikes, after controlling for investment opportunities. It suggests that managers at firms with good governance are less likely to pursue large investments.

In addition, Titman et al. (2004) utilize the measure of abnormal capital investment to estimate the extent of over-investment, and document a significantly negative association between abnormal capital investment and future stock returns. Further, Titman et al. (2004) find that the association between abnormal capital investment and stock return disappears during the period when the hostile takeover is quite prevalent, suggesting that if managers are disciplined by an active takeover market, they are less likely to engage in over-investment. Therefore, we opt for both Whited's (2006) hazard estimation and Titman et al.'s (2004) abnormal capital investment measure to gauge to what extent managers are tend to build up their empires.

Meanwhile, managers also have incentives to manage reported earnings both upward and downward. Teoh et al. (1998) argue that managers at firms that are about to issue seasoned equity have incentives to manage the pre-issue earnings upward. On the basis of seasoned equity issuers from 1976 to 1989, they find that issuers who inflate reported earrings will exhibit a lower post-issue net income and stock returns. By using 159 reissues of executive stock options, Coles et al. (2006) find that managers tend to manage reported earnings downward for their own benefit around the cancelation and the following reissuance of executive stock options. Gong et al. (2008) find that during 1984 to 2002, managers have propensity to deflate the earnings before stock repurchase and the distorted accruals prior to repurchase are negatively related to the post-repurchase performance. In the meantime, the literature has shown that distortion of accounting information, to some extent, is costly for shareholders. ${ }^{14}$ Thus, we also use earnings management, as a good empirical setting, to examine to what extent the intensive institutional trading could discourage managers from indulging in self-benefit, yet potentially value-destroying behaviors.

\footnotetext{
${ }^{14}$ See also Karpoff, Lee, and Martin (2008) and Karpoff and Lou (2010).
} 


\section{Data and Key Variables}

\subsection{Data}

Our data consists of all companies listed on the NYSE, AMEX, and NASDAQ from 1980-2011. We obtain stock price, stock return, trading volume data, and the number of shares outstanding from Center for Research in Security Prices. Relevant accounting data is derived from COMPUSTAT. Our primary data on institutional trading is derived from the Thomson-Reuters Institutional Holdings (13F) Database. The data for construction of the scaled wealth-performance sensitivity (WPS) is from Execucomp. ${ }^{15}$

\subsection{Measure of the reward-punishment intensity from institutional investors}

The measure of the reward-punishment intensity from institutional investors for firm $i$ in year $t$ is as follows:

$$
R P I_{i, t}=\log \left(\sum_{q=1}^{4} \sum_{j \in Q}\left|N_{j, i, q}-N_{j, i, q-1}\right|\right),
$$

where $N_{j, i, q}$ denotes the number of shares held by institutional invest $j$ at the end of quarter $q$. $Q$ denotes all institutional investors who hold the stock of firm $i$ in quarter $q$. This is a noisy measure for the total amount of institutional trading in year $t$, and represents the reward-punishment intensity from institutional trading that managers might confront in the following year.

The construction of RPI is in the same spirit to the investor churn rates measure in Gaspar et al. (2005). The main difference is that we focus on the changes in institutional holding at the firm level, whereas Gaspar et al. (2005) focus on the portfolio rotation rate of the institutional investors. Further, Edmans and Manso (2011) argue that trading volume itself is positively related to price efficiency and manager's effort, we therefore focus on simple measure of total absolute position changes of institutional investors in one year. ${ }^{16}$ In untabulated tests, we estimate the partial autocorrelation in RPI up to lag 5 years. We find a mild autocorrelation of $25 \%$ for the first lag, and not significant for beyond the first one. The time-varying feature of RPI provides a better

\footnotetext{
${ }^{15}$ We thank Alex Edmans for the data of WPS on his website.

${ }^{16}$ We obtain qualitatively the same results when we scale the RPI with total number of shares outstanding.
} 
identification of the governance effect on firm values and managerial misbehavior in the time-series, compared with the highly persistent G- or E-Index.

Table 1 reports summary statistics for variables used in the analysis. The number of firm-year observations varies from 114,372 to 19,824 mainly due to the limited availability of governance factors like G- and E-Inex. Our main variables of interest are reward-punishment intensity (RPI) from institutional trading, abnormal capital investment (CI), and performance-matched discretionary accrual (EM). RPI is constructed according to Eq.(1), and exhibits a mean value of 14.19 with a standard deviation of 2.76. CI represents the abnormal capital investment. It is computed according to Eq.(3), and has a mean value of 0.026 with standard deviation of 0.77 . EM is constructed according to Appendix B, which exhibits a mean value of 0.07 with a standard deviation of 0.09 .

\section{Basic Empirical Results}

\subsection{RPI and future stock returns}

\subsubsection{Sorting analysis}

In this section, we examine whether the level of RPI measure affects firm's future stock returns. We first investigate the raw returns in univariate analysis, and then we analyze the abnormal returns to account for well-established risk factors.

In Panel A of Table 2, we sort stocks into three groups (bottom 30\%, medium 40\%, and top $30 \%$ ) according to the RPI, and then examine the subsequent monthly returns. The value weighted monthly returns for stocks in High, Median, and Low RPI group are 1.12\%, 0.75\%, and 0.62\%, respectively. The difference between the High RPI group and the Low RPI group is statistically and economically significant, with $0.50 \%$ per month and a t-statistics of $2.78 .{ }^{17}$

In Panel B-D of Table 2, we report the portfolio returns, double sorted based on firm characteristics and the RPI, in order to control for potential effects from other firm characteristics. First, we sort stocks into three groups (bottom 30\%, medium 40\%, and top 30\%) according to the firm characteristics, namely size, book-to-market ratio, and momentum. We employ three groups to

\footnotetext{
${ }^{17}$ Value-weighted return has also been employed in Ang, Hodrick, Xing, and Zhang (2006), among others.
} 
assure sufficient number of observations and diversifications. Group 1 and Group 3 represents the lowest and highest values of each of firm characteristics, respectively. Second, we divide each group into three RPI subgroups, High RPI (top 30\%), Median RPI (medium 40\%), and Low RPI (bottom $30 \%$ ). In general, double-sorting results provide supportive evidence on the positive association between RPI and future stock returns. All of the return differences between High RPI group and Low RPI group are positive, and in most cases significant. In general, high RPI stocks outperform low RPI stocks in different size, book-to-market ratio, and momentum portfolios.

\subsubsection{Risk-adjusted return of long-short strategy based on the RPI}

Next, we form long-short portfolios, and then perform time series regression to account for the effect of well-known risk factors. We form stocks into deciles based on firm's RPI measure in the previous year. ${ }^{18}$ We then compute the return in the following 12 months on a zero-cost portfolio that longs the stocks in the top RPI decile and shorts the stocks in the bottom RPI decile. By repeating this process, we generate a time series of returns for the long-short portfolio. We then regress the return of the long-short portfolio on different risk factors. We perform four different models, including market model, Fama and French (1993) three-factor model, Carhart (1997) four-factor model, and Pastor and Stambaugh (2003) liquidity five-factor model. If the effect of the RPI on future stock returns stems from one of these five factors, we would find insignificant intercepts (alphas).

Table 3 presents the risk-adjusted return of long-short strategy based on the RPI. In general, this table supports the results in the sorting analysis, suggesting that there is a significant relation between the RPI and future stock returns even after accounting for market, size, book-to-market ratio, momentum, and liquidity factors. In particular, the monthly alpha for these four models are $0.58 \%, 0.62 \%, 0.66 \%$, and $0.66 \%$, respectively. The loadings on market factor and book-to-market ratio is significantly positive, suggesting that the zero-cost strategy that long high RPI stocks and short low RPI stocks has a positive exposure on stocks with small market capitalizations and stocks with high book-to-market ratio.

\footnotetext{
${ }^{18}$ To save space, we do not report the results of the long-short portfolio based on 3 groups of RPI, though the results are qualitatively similar.
} 


\subsubsection{Fama-Macbeth regression and panel regression}

In this section, we perform Fama and MacBeth (1973) cross-sectional regression to examine whether the effect of RPI on future stock returns holds after controlling for other firm characteristics and welldocumented cross-sectional determinants of stock returns. ${ }^{19}$ In particular, we include a set of control variables, namely firm market capitalization, book-to-market ratio, 12-month lagged stock returns, total accruals (Sloan (1996) and Hirshleifer, Hou, Teoh, and Zhang (2004)), asset growth (Cooper and Haltiwanger (2006)), illiquidity (Amihud (2002)), and sales growth (Lakonishok, Shleifer, and Vishny (1994)), fraction of institutional ownership (IOR) (Gompers and Metrick (2001)), G-Index (Gompers et al. (2003)), and E-Index (Bebchuk et al. (2009)). To be included in our sample, firms must have the data for the following variables: RPI, market capitalization, and book-tomarket ratio. The standard errors from the regressions are adjusted for Newey-West (1987) 12-lag autocorrelation.

In model 1 of Table 4, we present the results of cross-sectional regressions, including market capitalization and book-to-market ratio as control variables. The effect of RPI is not offsetted by these two major determinants of cross sectional stock returns. In fact, the coefficient on RPI is strongly statistically significant, with a t-statistic of 5.87. It suggests a positive relationship between RPI and future stock returns. In model 9 of Table 4, we include 8 other control variables. RPI is not subsumed by the other determinants of the cross sectional stock returns, and appears to be the third strongest determinants, in terms of t-statistics. Actually, the coefficient on RPI is 0.0037, with a t-statistic of 5.83, confirming the significant and important association between RPI and return documented in previous sections. The coefficients on market capitalization, asset growth, and total accrual are significantly negative, which is consistent with the literature. The coefficient on Amihud's illiquidity measure is statistically significant, with the right sign as literature predicted. The book-to-market ratio exhibits the expected sign on the coefficient, while not significant.

Next, we examine whether the effect of RPI on stock return remains after we control for the influence of G-Index and E-Index. Since we should merge our data with the data of G-Index and E-Index, the size of the sample decreases dramatically. We find that the RPI remains strongly

\footnotetext{
${ }^{19}$ Because the power issue with the annual return regression, we employ monthly returns as dependent variable for the tests. The results of annual returns are qualitatively similar as well.
} 
significant in these two models with corporate governance provisions controlled; in model 10 of Table 4, with G-Index, the t-statistics for the coefficient on RPI is 7.17; in model 11 of Table 4, with E-Index, the t-statistics for the coefficient on RPI is 5.55.

Since Petersen (2009) argues that the standard errors from panel data would be more reliable if they are clustered at both firm and year, we also examine whether our results are biased based on Petersen's technique. The results in Table 5 suggest that the effect of RPI on stock returns still remains even after adjusted for more conservative standard-error estimates. In all models, the coefficients on the RPI are statistically and economically significant. For example, in the three most comprehensive models 9, 10, and 11, the t-statistics for coefficients on RPI are 7.04, 6.62, and 6.92, respectively.

Consistent with the first hypothesis, the results thus far indicate that the RPI is positively related to subsequent stock returns, and the predictable power of RPI is not subsumed by previously documented predictors of the cross-section of stock returns. future stock returns.

\subsection{RPI and subsequent Tobin's Q}

In this section, we investigate the association between RPI and subsequent Tobin's Q. Following Kaplan and Zingales (1997), Gompers et al. (2003), and Bebchuk and Cohen (2005), we define the Tobin's $\mathrm{Q}$ as the ratio of market value of assets and the book value of assets. Market value of assets is defined as the difference between the sum of the book value of assets and the market value of common stock and the sum of book value of common stock and balance sheet-deferred taxes.

We perform eight regressions. We include the log of the assets of the firm, firm age based on the first date appears in Compustat(Shin and Stulz (2000)), return on assets, the ratio of research and development expenditures to total sales ( $\& \& D /$ sales), insider ownership (fraction of shares held by insiders), and insider ownership squared (Bebchuk and Cohen (2005)). In the last two specifications, we include the G-Index (Gompers et al. (2003)) and E-Index (Bebchuk et al. (2009)) to control for corporate governance provisions. We also include the dummies for Fama and French's (1997) 48 industry groups. In all regressions, we employ Petersen (2009) method to cluster both at firm and year. 
Model 1 of Table 6 includes only the RPI and the logarithm of total assets. As the result indicates, RPI is positively associated with firm value in the subsequent year, reflected by Tobin's Q. We then control for other variables, listed in the prior paragraph. In the most comprehensive specification model 6 , the result indicates that the coefficient on RPI remains statistically and economically significant. From 1980 to 2011, a one-standard-deviation increase in RPI leads to 0.46 standard deviation improvements in firm's Tobin's Q in the following year, after controlling for other firm value relevant variables. As for the control variables, it is worth noting that the coefficient on insider ownership are positively significant and coefficient on insider ownership squared is negatively significant. It indicates the nonlinear (hump shaped) relationship between insider ownership and firm value.

We next control for the corporate governance provisions, as suggested in Gompers et al. (2003) and Bebchuk et al. (2009). In this paper, we attempt to argue that the intensive institutional trading could be treated as a discipline force, by hindering managers from value-destroying behaviors. Both Gompers et al. (2003) and Bebchuk et al. (2009) find G-Index and E-Index are associated with firm value, respectively. Thus, it raises a question whether the identified positive relation between RPI and firm value is driven by corporate governance provisions that firms with higher RPI might have. We perform the regression and control for the potential effect of G-Index and E-Index. Model 7 and Model 8 of Table 6 display the results. It is noteworthy that after the inclusion of G-Index and E-index, the coefficient on RPI remains strongly significant. It indicates that the corporate governance provisions might not drive the documented effect of RPI on firm value. In addition, the coefficient on E-Index is negatively significant, consistent with the results in Bebchuk et al. (2009). The coefficient on G-Index is also negatively significant, which is in line with the finding in Gompers et al. (2003).

Of course, the documented effect of RPI on both future stock returns and subsequent firm values is consistent with our first hypothesis, and the effect also motivates us to ask how RPI ("Governance Through Trading") would affect firm value. To shed further light on this, in the next section of the paper we examine whether RPI ("Governance Through Trading") would mitigate the tendency of managers to undertake value-destroying activities, such as empire building and earnings management, which then improves firm value. 


\subsection{RPI and managerial value-destroying behaviors}

Having identified a positive association between intensive institutional trading and subsequent stock returns (firm value), we now turn to the test of our second hypothesis: the relation between institutional trading and managerial value-destroying behaviors.

\subsubsection{RPI and Empire Building: Hazard Estimation}

In this section, we carry out the hazard estimation discussed in Appendix A. Our hazard estimate stresses the probability of undertaking a large investment conditional on the time passes since the last large investment. Following Whited (2006), we also opt for the technique introduced in Meyer (1990), which accounts for both time-varying covariates and unobserved heterogeneity. The hazard function is composed of two parts. The first part is the baseline hazard, which is common to all firms. The second part is the time-varying explanatory variables, which impacts the shape of the hazard function. In particularly, the technique allows the hazard rates shift upward or downward according to the value of the covariates, incorporates the cross-sectional heterogeneity, and accounts for the right-censoring of our data due to the fact that firms have not yet experience large investments at 2011.

Our second hypothesis suggests that the firms with higher RPI less likely to experience overinvestment frequently. Thus, we carry out the hazard estimation as follows:

$$
\lambda_{i}(t)=\omega_{i} \lambda_{0}(t) \exp \left(R P I_{i, t} \cdot \gamma_{1}+x_{i}(t)^{\prime} \cdot \beta\right)
$$

where $R P I_{i, t}$ denotes the reward-punishment intensity of institutional investors in period $t . x_{i}(t)^{\prime}$ represents a column vector of covariates value in period $t$, including total assets, sales growth, cash flow, and leverage. Following Whited (2006) and Billett et al. (2011), we measure the investment rate as the difference between capital expended and sale of property, scaled by total asset. Investment spike is an indicator, which equals to one if the firm's investment rate in year $t$ exceeds pre-defined benchmark, otherwise zero. We also define the benchmark as 2, 2.5, and 3 times of the median of the firm's investment rate in our sample as in Whited (2006). 
Because the variables of interest in Whited (2006) and Billett et al. (2011), e.g., number of business segments and G-Index, are time-invariant, they need to sort sample firms into two groups based on those variables and then compare the shape of the baseline hazard function to examine the hazard rate of over-investment. ${ }^{20}$ However, our RPI measure is time-varying by its construction, with a relatively low first lag autocorrelation of $25 \%$. We thus could include RPI as a time-varying covariate and test our hypothesis by estimating directly the coefficients on RPI, $\gamma_{1}$, rather than comparing the baseline hazard functions for two groups of firms sorted by the variable of interest. ${ }^{21}$ As we argue that managers in high RPI firms are less likely to engage in over-investment (empire building), we would expect a negative $\gamma_{1}$, suggesting a negative marginal effect of RPI on the hazard rate.

Table 7 reports the results of estimating the Whited's (2006) hazard models according to Eq.(2). As discussed in last paragraph, a positive coefficient on a particular variable suggests a positive incremental effect on the hazard rate. In contrast, a negative coefficient on a particular variable indicates that the hazard rate is decreasing with that variable, and thus lowers the probability of over-investment. In the first two models, the indicator of the investment spike (over-investment) equals to one when firm's investment rate in this year is larger than the 2 times of the median value of the firm's investment in whole sample. Similarly, in model 3 - model 6 , the indicator equals to one when the firm's investment rate in current year is larger than 2.5 times or 3 times of the median value. Across all models, we find that the $\gamma_{1}$ is negative and significant, suggesting that the intensity of institutional trading is negatively associated with the hazard rate of over-investment. In model 1, a one-standard-deviation increase in RPI leads to $9.45 \%$ decrease in the hazard of overinvestment. In addition, a one-standard-deviation increase in RPI leads to $8.94 \%$ decrease in the hazard of over-investment in model 3. It is also noticeable that the coefficients on sales growth are positive and significant, indicating that managers are more likely to invest in "empire" when firms performance is good.

In order to address the effect of governance provision on over-investment documented in Billett

\footnotetext{
${ }^{20}$ If one group's baseline hazard lies below the hazard for the other group, firms in the first group less likely experience over-investment.

${ }^{21}$ Our method is in the similar spirit as Hazarika et al. (2012), who employ proportional hazard model and find that the likelihood of CEO's forced turnover in year $t$ is increasing with the extent to which he manipulates reported earnings in year $t-1$.
} 
et al. (2011), we control for the number of G-Index in model 2, 4, and 6, and $\gamma_{1}$ remains significant and negative. It is worthy of noting that the coefficient on G-Index is positively significant, which is consistent with Billett et al.'s (2011) finding that good corporate governance might hinder managers from over-investment. Overall, these results indicate that the over-investment is less likely when the institutional trading is intensive, which is consistent with our second hypothesis.

\subsubsection{RPI and Empire Building: Abnormal Capital Investments}

Following Titman et al. (2004), we compute the abnormal capital investment $\left(C I_{t}\right)$ in year t as follows:

$$
C I_{t}=\frac{C E_{t}}{\left(C E_{t-1}+C E_{t-2}+C E_{t-3}\right) / 3}-1
$$

where $t$ represents the year when the abnormal capital investment is computed, and $C E_{t}$ is a firm's capital expenditure (CAPEX) scaled by its total asset (TA) in year $t$.

We then investigate whether institutional trading affects firm's abnormal capital investments in the following year. In particular, we perform the following panel regression, where t-statistics are based on the standard errors clustered at both firm and year level (Petersen (2009)):

$$
\begin{aligned}
& C I_{i, t+1}=a_{0}+a_{1} \times R P I_{i, t}+a_{2} \times S I Z E_{i, t}+a_{3} \times \text { BM }_{i, t}+a_{4} \times \text { Leverage }_{i, t} \\
& +a_{5} \times \text { FixedAsset }_{i, t}+a_{6} \times \text { CashFlow }_{i, t}+a_{7} \times \text { ROA }_{i, t}+a_{8} \times \text { SaleGrowt }_{i, t} \\
& +a_{9} \times \text { Tobin's }^{\prime} Q_{i, t}+a_{10} \times G-\text { Index } \text { E }- \text { Index }_{i, t}+\epsilon_{i, t}
\end{aligned}
$$

where the dependent variable, $C I_{i, t+1}$ is computed following the specification in Eq.(3). RPI is our main variable of interest, constructed according to Eq.(1). To control for other effects that might influence our results, we include the log of market capitalization, book-to-market ration, the ratio of debt and total assets, the ratio of fixed assets and total assets, the cash flow scaled by total asset, the ratio of net income to total assets, the changes in sales scaled by lagged sales, Tobin's Q, and G-Index or E-Index as control variables. We also include the 48 industry dummies (Fama and French (1997)), and employ the standard error that clustered at both firm and year level.

Table 8 presents the results of the panel regressions. Consistent with our second hypothesis, the coefficient on RPI is negatively significant across all specifications, suggesting that firms with 
intensive institutional trading whose managers are less likely to engage in over-investment. In model 8, we include all control variables listed in the preceding paragraph except for the proxy for governance provisions. Results suggest that the effect of RPI on over-investments is not only statistically significant, but also economically important. A one-standard-deviation increase RPI results in 0.17 standard deviation decrease in abnormal investment rate in the overall sample, with all investment relevant variables controlled. It is noteworthy that the coefficient on book-tomarket ratio, as a proxy for growth opportunities, is negatively significant. It suggests that the firm's investment is positively related with growth opportunities, consistent with existing literature (Richardson (2006)).

We next control for the effect of corporate governance provisions on over-investment. Billett et al. (2011) have documented a significant effect of G-Index on over-investment. Since we attempt to identify the discipline effect of institutional trading on over-investment, it is necessary to rule out the possibility that the association between RPI and over-investment is due to firm's corporate governance provisions. Similar to Section 4.1 and 4.2 , we include two proxies for corporate governance provisions, G-Index and E-Index. Owing to the reduction in the number of the observations, we would not expect the statistical significance to be completely consistent with other models. While the results from these two model are fairly robust, although the coefficients on RPI become less significant. These results provide evidence that a higher level of RPI could help to reduce over-investment in the subsequent year.

\subsubsection{RPI and Earnings Management}

Analogous to the analysis in preceding sections, we examine the effect of RPI on earnings management. We carry out the following panel regression, with t-statistics adjusted for standard errors clustered at both firm and year level (Petersen (2009)):

$$
\begin{aligned}
& E M_{i, t+1}=a_{0}+a_{1} \times R P I_{i, t}+a_{2} \times S I Z E_{i, t}+a_{3} \times B M_{i, t}+a_{4} \times A G E_{i, t} \\
& +a_{5} \times \operatorname{Capx}_{i, t}+a_{6} \times \text { CashFlow }_{i, t}+a_{7} \times R O A_{i, t} \\
& +a_{8} \times G-\text { Index } / E-\text { Index }_{i, t}+\epsilon_{i, t}
\end{aligned}
$$


where the dependent variable, $E M_{i, t+1}$ is computed as the absolute value of $\alpha_{i, t}$, according to the methodology in Appendix B. We construct the measure of RPI according to Eq.(1). To address other effects that might influence earnings management, we control for the log of market capitalization, book-to-market ration, the firm age, the ratio of capx and total assets, the cash flow scaled by total asset, the ratio of net income to total assets, and G-Index or E-Index as control variables. We also control for (Fama and French (1997)) 48 industry dummies, and employ the standard errors that are clustered at both firm and year.

Table 9 presents a strong relation between RPI and earnings management, which remains across different specifications and is both statistically and economically significant. In model 6 of Table 9 , our result shows that a one-standard-deviation increase in RPI (19.45\% in our sample) is associated with an $5.56 \%$ decline of absolute value of the performance-augmented discretionary accrual in the next year. As for the control variables, we find that large firm is less likely to manipulate earnings information, which is consistent with the finding in Cohen, Dey, and Lys (2008). The coefficient on ROA is negatively significant, suggesting that managers tend to manage earnings when performance is poor.

In models 7 and 8 of Table 9 , we control for the effect of corporate governance provisions. Similar to the results in Section 4.3.2, we find the effect of RPI on earnings management still holds even after controlling for G-Index and E-Index, though less significant as a result of reduced sample size. Overall, these results thus far are supportive to our second hypothesis, indicating that intensive institutional trading is an important factor that affects the incentives of managers to engage in self-interest, yet value-destroying activities, namely empire building and earnings management. The effect remains strong and significant after controlling for a set of variables that might impact managerial behaviors.

\section{Additional Supporting Evidence}

In order to substantiate our understanding of the discipline effect of institutional trading, we further investigate the interaction effect between RPI and other variables that are shown to have governance effect. Our goal is to understand whether the discipline effect of RPI will be complemented or substituted. Specifically, we examine the following factors: Decimalization (Bharath et 
al. (2012) and Edmans et al. (2013)), the Amihud (2002) illiquidity estimation, institutional ownership concentration (Kim and Lu (2011)), the Edmans et al. (2009) wealth-performance sensitivity measure, the Kaplan and Zingales (1997) financial constraints index (KZ index), and the takeover wave (Titman et al. (2004)).

\subsection{Decimalization and Amihud Illiquidity Measure}

Both Bharath et al. (2012) and Edmans et al. (2013) document that liquidity, either in the form of positive liquidity shock (Decimal) or in the form of high stock liquidity (ILLIQ), imposes governance effect, by strengthening the threats of exit and then enhancing the link between blockholder ownership and firm values. Our identification strategy also employs decimalization dummy variable and Amihud ILLIQ measure. From January 29, 2001, the New York Stock Exchange (NYSE) started quoting and trading its listed stocks in dollars and cents rather than increments of a sixteenth of a dollar, i.e., switching from sixteenth to decimal price. Furbine (2003) and Bessembinder (2003) demonstrate that the trading liquidity improved after the decimalization on the NYSE and the NASDAQ. In addition, Amihud (2002) constructs the measure of illiquidity, which computes the marginal transaction cost (stock price changes) associated with one dollar trading volume. Goyenko, Holden, and Trzcinka (2009) find that Amihud IILIQ measure reflects the trading cost most accurately among 12 other daily data based liquidity measures. Based on these two forms of liquidity measure, we examine whether a greater degree of liquidity will enhance the link between RPI and the following agency costs, as firms with higher trading liquidity whereby institutional investors would be easily to reward and punish managerial behavior by buying and selling firm shares.

On the basis of the model 8 of Table 8 and model 6 of Table 9 , we include the dummy variable for decimalization, the Amihud (2002) illiquidity measure and their interaction terms with RPI. ${ }^{22}$ It is noteworthy, as analytically discussed, that columns 2 in Table 10 and Table 11 show that the interaction terms between RPI and Decimalization dummy are negatively significant, indicating that the intensive institutional trading will be more effectively to hinder empire building and earnings management in the post-decimalization period. Likewise, columns 4 in Table 10 and Table 11 show

\footnotetext{
${ }^{22}$ We choose these two model specifications, since they have all important control variables and quite sufficient sample size. We would use these two specifications to examine the interaction effects of the RPI with other known governance factors, including IOC, WPS, and KZ index.
} 
that the interaction terms between RPI and ILLIQ are positively significant, which is consistent with our conjecture that higher stock liquidity would reinforce the discipline effects of the RPI. Overall, our results indicate that the RPI and the stock liquidity are complements in deterring managers from empire building and earnings management.

\subsection{Institutional Ownership Concentration}

Firms with lower institutional ownership concentration (IOC) makes the direct intervention by institutional investors more difficult, as the benefits from activism might not be sufficient to offset the costs incurred. Edmans and Manso (2011) argue that in spite of the hindering of the intervention, low institutional ownership concentration reinforces another discipline force, "Governance Through Trading". ${ }^{23}$ We therefore would expect to see a stronger negative link between the RPI and managerial value-destroying behavior in firms with lower IOC.

Following Hartzell and Starks (2003) and Kim and Lu (2011), we use the sum of the top five institutional investors share ownership as the proxy for institutional ownership concentration (IOC). The empirical results are included in models 5 and 6 in Table 10 and Table 11. It is noteworthy that we find that lower level of IOC strengthens the negative relation between RPI and value destroying behaviors, as indicated by the positively significant coefficients on the interaction terms between IOC and RPI. In column 6 of Table 10, the coefficient on interaction between RPI and IOC is 0.0977, with a t-statistics of 1.74. In column 6 of Table 11, the coefficient on interaction between RPI and IOC is 0.0056 , with t-statistics of 1.96 . Overall, these results confirm our prediction that discipline effect of institutional trading on value-destroying behaviors is pronounced in firms with a lower level of institutional ownership concentration, which is consistent with the argument in Edmans and Manso (2011). In addition, as can be seen from the tables, the coefficient on IOC is negatively significant, which also corroborates the argument in Edmans and Manso (2011) that higher ownership concentration is associated with lower agency costs owing to investors' activism.

\footnotetext{
${ }^{23}$ Previous studies provide mixed evidence on institutional activism. On the one hand, empirical studies provide evidence that institutional investors lack ability to intervene (Black (1990) and La Porta, Silanes, and Shleifer (1999)). On the other hand, other studies show that institutional investors have impact on firm decisions (Chen, Harford, and Li (2007) and Cronqvist and Fahlenbrach (2009)). The idea of "Governance Through Trading", introduced in Edmans and Manso (2011) might reconcile these two conflicting observations, by providing a different perspective of governance force.
} 


\subsection{Wealth Performance Sensitivity}

The mechanism of "Governance Through Trading" indicates that the institutional trading would have impact on stock prices, which in turn alters managers' activities owing to the managerial equity compensation. Therefore, the effectiveness of "Governance Through Trading" is largely dependent on the extent to which managers compensation is related to stock price (Admati \& Pfleiderer, 2009; Edmans, 2009; Edmans \& Manso, 2011). In this section, we investigate whether managers compensation would complement or substitute the impact of institutional trading on empire building and earnings management.

Following Edmans et al. (2009), we use the measure of wealth-performance sensitivity (WPS), which represents the dollar change in CEO wealth for a 100 percentage point change in firm value, scaled by annual flow compensation. ${ }^{24}$ We would expect to see a negatively significant coefficient on the interaction terms, indicating that WPS should complement the discipline effect of RPI on valuedestroying activities. In columns 8 in Table 10 and Table 11, the coefficients on the interactions between WPS and RPI are indeed positive and significant, suggesting that, everything else equal, the discipline force of institutional trading on empire building and earnings management will be more effective when managers' wealth is more sensitive to stock prices. Overall, these results suggest that the governance effect of institutional trading will be more pronounced for managers who are sufficiently cared for their equity-based wealth.

\subsection{Financial Constraints}

Whited (2006) argues that financial constraints may bring in extra costs when adjusting the capital, and then reduce over-investments. Billett et al. (2011) find there are no effects of corporate governance provision (G-Index) on the over-investment when firm is financial constrained, indicating that governance and financial constraints are substitutes in mitigating managers' incentives to overinvest. We therefore expect the discipline effect of the RPI would be offsetted in firms with a higher degree of financial constraints. Column 10 in Table 10 presents the results. The coefficient on the interaction term is positive and significant, indicating that a higher level of $\mathrm{KZ}$ index (more financial

\footnotetext{
${ }^{24}$ See Edmans et al. (2009) for detailed information.
} 
constrained) will offset the discipline effect of intensive institutional trading on over-investment. In other words, mangers in financial constrained firms are less likely to build up empire, as analytically predicted. Noteworthy, Column 9 in Table 10 shows that the coefficient on KZ index is negative and significant. It indicates that financial constrained firms are less likely to over-invest, consistent with the findings in Whited (2006) and Black (1990). Overall, we find that the degree of financial constraints and the discipline effect of RPI are substitutes in mitigating the propensity of managers to over-invest.

\subsection{Hostile Takeover Wave}

Titman et al. (2004) suggest that during the wave of hostile takeover and merger activity, managers with empire building propensity were forced to pursue more value-enhancing project to deter these takeovers and secure their own jobs. Thus, we follow Titman et al. (2004), and define the hostile takeover wave dummy equals to one when it is from 1984 to 1989, otherwise zero. We examine not only whether this dummy would subsume the effect of the RPI, but also what is the interacted effect between takeover wave and the RPI measure. Table 10 presents the results. In all models in Table 10, we add takeover dummy as control variable, and find the coefficients are all negative and most of them are significant, which is consistent with the finding in Titman et al. (2004). In particular, in model (12) of Table 10, we interact the takeover dummy with the RPI measure, and find that the coefficient is positively significant, suggesting that the RPI and takeover wave are substitutes for deterring managers from empire building.

\section{Robustness Tests}

In this subsection, we conduct three robustness tests for our main result that higher past RPI leads to higher firm value by reducing the managerial propensity of empire building and earnings management. We first show that main findings remain when we exclude firms with increased institutional ownership ratio. Second, we employ mean RPI of all firms in the same state, same year, and same industry as the IV for the RPI and find the similar results. Third, we perform a set of robustness regressions, by controlling for the firm fixed effects. 


\subsection{Subsample analysis of firms tb12with institutional ownership ratio below the median}

Nofsinger and Sias (1999) and Yan and Zhang (2009) find that institutional investors' holdings forecast future stock returns, indicating that some institutional investors possess private information. $^{25}$ Therefore, one may be concerned that the lead-lag relation between RPI and firm value and managerial behavior might simply reflect the private information held by institutional investors rather than the discipline effect of institutional trading on managerial behaviors. In other words, when institutional investors have positive private information about higher firm value and better managerial behaviors, they would buy more shares, which results in the lead-lag relation between RPI and firm value and managerial activities. If this is the case, the improved firm value and disciplined managerial behaviors that we observe can be purely from the information-driven institutional investor position changes rather than from the discipline effect of the RPI, i.e., governance through trading.

To address this potential concern, we first re-run our estimation, by excluding firm-year observations that have four consecutively positive quarterly position changes of institutional investors. Through year 1980-2010, 9,652 firm-year observations are excluded. We obtain largely similar results and do not report these results for brevity. Next, we categorize firms according to the changes in institutional ownership ratio $(\triangle I O R)$, and only include firms whose $\Delta I O R$ below the median in that year in the estimation. ${ }^{26}$ The intuition is that if institutional trading only contains information but has no discipline effect on managerial misbehaviors, we should observe that the higher the RPI for firms with reduced institutional ownership ratio, the lower the firm value should be. The results in Table 12 reveal the opposite. In the first column, we report the result of risk-adjusted return of long-short strategy based on the RPI. In this subsample, we find that the monthly alpha for five factor model is $0.5 \%$, only slightly less than that of the whole sample yet quite significant $(0.66 \%$, See Table 3). In the second column, we regress the Tobin's Q in the following year on the RPI and other control variables, and find that the coefficient on the RPI is 0.2264 with t-statistic of 9.13.

\footnotetext{
${ }^{25}$ Gompers and Metrick (2001) also document a positive association between institutional holding and future stock returns, while they attribute this association to the demand of institutional investors.

${ }^{26}$ In our sample, those firms experience $4 \%$ reduction in institutional ownership ratio on average, which is statistically significant.
} 
In the third column, we regress the subsequent monthly stock return on the RPI, and find that the relation between the RPI and stock return is still positive and significant. In column 4 and column 5, we regress the CI and EM on the RPI, respectively, and find that the negative associations between the RPI and managers value-destroying behaviors remain. These results suggest that the positive association between the RPI and subsequent firm value and the negative associations between the RPI and subsequent value-destroying behaviors are not purely driven by information held by institutional investors. This further supports our hypothesis that high RPI exerts discipline effect on managerial behaviors.

\subsection{Instrumental variable for RPI}

In section 5.1, we show that the positive exogenous liquidity shock of decimalization helps to improve the governance effect of RPI. The result, together with the fact that the RPI, unlike the E-index or G-index, is time-varying, helps to alleviate the concern of the endogeneity. In this subsection, we further address the endogeneity issue by employing the mean RPIs of peer firms as instrumental variables (IV). In particular, we employ the mean RPI of all firms (excluding firm $i$ 's own RPI value) in the same state, same year, and same industry, RPI_SYI(- $i)$, as our IV for the RPI. Kim and Lu (2011) argue that institutional investors might have same preference for specific firm locations and industries, we therefore argue that RPI_SYI(- $i$ ) is associated with firm $i$ 's own RPI, but may not be related to firm $i$ 's firm value and manager's activities. ${ }^{27}$

Table 13 presents the results of instrumental variable regressions. In the first stage, we regress the RPI on RPI_SYI(- $i$ ) and other control variables. All regressions control for industry- and yearfixed effects, and standard errors are clustered at the firm level and adjusted for heteroscedasticity. ${ }^{28}$ In the second stage, the predicted values are employed as main explanatory variable. The results are robust regardless of whether G-Index or E-Index is included, providing supportive evidence that higher RPI would improve firm value by deterring managers from undertaking empire building and earnings management.

\footnotetext{
${ }^{27} \mathrm{Kim}$ and $\mathrm{Lu}$ (2011) employ the average institutional ownership concentration (IOC) of peer firms in the same state, same year, and same industry as IV for firm $i$ 's IOC, and find it alleviates the effect of CEO ownership on firm value.

${ }^{28}$ The results of first stage is not tabulated for brevity. We find that the RPI is strongly positively associated with the mean RPIs of peer firms, suggesting that the mean RPIs of peer firms could indeed serve as an IV for the RPI.
} 
A potential concern of the previous IV construction is that the agency costs are contagious within an industry. One firm's managerial misbehavior makes institutional investors wary of the other firms' managers in the same industry irrespective of their actual behaviors and hence results in a spurious relation between the IV and the subsequent firm value as well as managers' activities. However, it is less likely that the contagion is from small firms to big firms. In other words, one small firm manager's misbehavior would not draw much institutional investors' attention of other big firms. We therefore re-run the IV estimation focusing on a big firm subsample which includes firms whose market capitalizations are greater than the median capitalization of all the firms in the same year, and employ the mean of RPI of small firms with market capitalizations below the median capitalization of all the firms in the same state, year, and industry as the instrumental variable, denoted as RPI_SYI $(-i)_{b}$. Using the same way in Table 13, we perform a two-stage-least-square regression for this big firm subsample, and the results are tabulated in Table 14. Model (1) shows a strongly positive relation between the instrumented RPI and the subsequent firm value. Models (2) and (3) show strongly negative relations between the instrumented RPI and the subsequent agency costs, namely empire building and earnings management. It suggests that our IV estimation results in Table 13 are not driven by the industry contagion.

\subsection{Firm Fixed Effect}

In order to rule out the possibility that our findings are driven by some unobserved firm fixed factors, we conduct several robustness regressions. Table 15 presents the results. In models (1), (4), and (7), we control for both firm and year dummies, and cluster the standard errors at firm level. We find consistent results that higher RPI leads to higher firm value, less empire building, and less earnings management. In models (2), (5), and (8), we control for both firm and year dummies, and cluster the standard errors at industry level. The results suggest a robust association among RPI, firm value, empire building, and earnings management. In models (3), (6), and (9), both year and industry dummies are controlled, and standard errors are clustered at firm level. We still find qualitatively similar results. In sum, results included in this section suggest that our primary findings are quite robust. 


\section{Conclusion}

In this paper, we identify an important mechanism through which the reward-punishment intensity (RPI) from institutional trading improves firm values and disciplines managerial valuedestroying behaviors. We document a positive correlation between the RPI and subsequent stock returns in the time period 1980 to 2011. On average, stocks with a higher lagged RPI will outperform stocks with lower lagged RPI by over $0.66 \%$ per month, after accounting for well-known risk factors, such as market, size, book-to-market ratio, momentum, and liquidity. Moreover, the association between the RPI and future stock returns is robust to a set of return anomalies, such as accrual and asset growth. We also find that the RPI is positively associated with firm's subsequent Tobin's Q, consistent with the notion of governance through trading.

Further, we provide evidence that the effect of RPI on the subsequent firm values can be attributed to the discipline effect of institutional trading on managerial value-destroying behaviors. We find that firms with higher RPI whose managers are less likely to undertake value-destroying behaviors, namely empire building and earnings management. Following Whited (2006), we employ hazard estimation to examine the marginal effect of institutional trading on hazard of overinvestment, and find that firms with higher RPI will have lower hazard rate of over-investment, compared with firms with lower RPI. By using the abnormal capital investments measure in Titman et al. (2004), we find similar evidence that the RPI is negatively related to the managers' propensity to over-invest. In addition, following Kothari, Leone, and Wasley (2005) and Hazarika et al. (2012), we utilize performance-matched discretional accrual to gauge the extent of earnings management. We find that managers at firms with higher RPI will be less likely to manage earnings information.

Moreover, we find a lower institutional ownership concentration and a higher level of wealthperformance sensitivity will enhance the discipline effect of institutional trading, consistent with the argument in Edmans and Manso (2011). We also find that the discipline effect of institutional trading is more prominent in firms with high liquidity, measured by Decimalization and Amihud ILLIQ, consistent with the evidence from Bharath et al. (2012) and Edmans et al. (2013). Besides, we also find the discipline effect of the RPI on empire building will be less significant in financial constrained firms, consistent with the finding in Billett et al. (2011). In robustness tests, we find 
that our main results remain, by using subsample firms with reduction in institutional ownership ratio and instrumental variable constructed by mean of peer firms' RPI in the same state, industry, and year. Overall, our findings suggest that intensive institutional trading increases firm value owing to the notion of "Governance Through Trading", which is recently proposed by Admati and Pfleiderer (2009), Edmans (2009), and Edmans and Manso (2011). We identify two potential channels, namely empire building and earnings management, through which the discipline effect of institutional trading might play a role. 


\section{Appendix A: Hazard Estimation for Empire Building}

Whited (2006) proposes a methodology to use hazard model to estimate the probability that a manager undertakes a large investment based on the time since the last large investment. ${ }^{29}$ She employs the estimation methodology in Meyer (1990), and starts with a proportional hazards specification with unobservable heterogeneity:

$$
\lambda_{i}(t)=\omega_{i} \lambda_{0}(t) \exp \left(x_{i}(t)^{\prime} \cdot \beta\right)
$$

where $\lambda_{0}(t)$ is the baseline hazard function, which is common to all firms. $\omega_{i}$ is a random variable and represents the unobservable heterogeneity, following Gamma distribution with unit mean and variance, $\sigma^{2} \cdot x_{i}(t)$ represents a vector of covariates which identifies observable differences across individual firms. $\beta$ is the vector of coefficients of those covariates accordingly. $\exp \left(x(t)^{\prime} \beta\right)$ allows the expected time of the occurrence of the investment "spike" to vary across firms according to their different value of the set covariates. $t$ represents the length of a spell, the duration between two adjacent large investments. Hazard rate, $\lambda(t)$, represents the probability of undertaking a large investments at time $t$ conditional on time elapsed since last large investments. Hazard estimation also allows for right-censored data. For example, if last recorded investment spike occurs in 2000 for firm $i$, and firm $i$ 's data ended in 2002, then the censored duration of firm $i$ 's final spell is two-year.

Maximum likelihood method is utilized to estimate the coefficients. Denote $T_{i}$ as the actual length of time between investment spikes and the censoring time as $C_{i}$ for firm i. Define $\delta_{i}=1$ if $T_{i} \leq C_{i}$ and 0 otherwise. Let $h_{i}=\min \left(T_{i}, C_{i}\right)$. The Log-likelihood function presents as follows:

$$
L(\gamma, \beta)=\sum_{i=1}^{N} \ln \left\{\left[1+\sigma^{2} \sum_{t=0}^{h_{i}-1} \exp \left(x_{i}(t)^{\prime} \beta+\gamma(t)\right)\right]^{\left(-1 / \sigma^{2}\right)}-\delta_{i}\left[1+\sigma^{2} \sum_{t=0}^{h_{i}} \exp \left(x_{i}(t)^{\prime} \beta+\gamma(t)\right)\right]^{-\left(1 / \sigma^{2}\right)}\right.
$$

where

$$
\gamma(t)=\ln \left(\int_{t}^{t+1} \lambda_{0}(s) d s\right)
$$

and $\sigma$ denotes the variance of the gamma distribution of the unobservable heterogeneity, $\omega_{i}$. The shape of the hazard is chosen to maximize the likelihood of observing the spells in the whole sample.

\footnotetext{
${ }^{29}$ Please refer to Whited (2006) for detailed analysis.
} 


\section{Appendix B: Computation of Performance-Augmented Discretionary Accruals}

Kothari et al. (2005) modify the traditional discretionary accrual measure, by controlling for the influence of prior firm performance. By matching the firm performance based on return on assets, Kothari et al.'s method rules out the predictable part of accruals which is performance-relevant, and then improves the accuracy and reliability of the measure of discretionary accruals.

Following Kothari et al. (2005), we first compute the total accrual for firm $i$ in year $t$ as follows:

$$
\text { TotalAccural }_{i, t}=\frac{\Delta C A_{i, t}-\Delta C L_{i, t}-\Delta \operatorname{Cash}_{i, t}+\Delta D E B T C L_{i, t}-D E P A M_{i, t}}{\text { TotAsset }_{i, t-1}}
$$

where $\Delta C A_{i, t}$ denotes the changes in current asset from year $t$-1 to year $t$ for firm $i ; \Delta C L_{i, t}$ denotes the changes in current liabilities from year $t$ - 1 to year $t$ for firm $i ; \Delta$ Cash $_{i, t}$ denotes the changes in cash from year $t-1$ to year $t$ for firm $i ; \triangle D E B T C L_{i, t}$ denotes the changes in debt in current liabilities from year $t-1$ to year $t$ for firm $i$; DEPAM denotes the depreciation and amortization expense for firm $i$ in year $t$; TotAsset denotes book value of total assets for firm $i$ in year $t$.

Second, we compute the performance-augmented discretionary accrual by regressing the total accrual on the inverse of total asset, the changes in revenues, then changes in account receivables, the gross value of PP\&E, and the return on assets according to the Eq.(B.2). In particular, it is estimated for each of Fama and French's (1997) 48 industry groups in each year $t$.

$$
\operatorname{TotalAccural}_{i, t}=\gamma_{0, i}+\gamma_{1, i} \frac{1}{\operatorname{TotAsset}_{i, t-1}}+\gamma_{2, i}\left(\Delta \operatorname{Rev}_{i, t}-\Delta A R_{i, t}\right)+\gamma_{3, i} P P E_{i, t}+\gamma_{4, i} \operatorname{ROA}_{i, t-1}+\alpha_{i, t}
$$

Following Klein (2002), Cohen et al. (2008), and Hazarika et al. (2012), we use the absolute value of the residual $\alpha_{i, t}$ from the above regression to measure the extent of earnings management, as managers have incentives to both inflate and deflate reported earnings (See Section 2.4 for more details). 


\section{Appendix C: Variable Definitions}

\begin{tabular}{|c|c|}
\hline RPI & $\begin{array}{l}\text { Natural log of the annual sum of the absolute value of quarterly changes in institutional holdings, } \\
\text { aggregated across all institutions of firm. These data are derived from } 13 \mathrm{~F} \text { quarterly holdings data. }\end{array}$ \\
\hline $\mathrm{BM}$ & $\begin{array}{l}\text { The ratio of the book value of equity divided by the market value of equity, as of the previous year } \\
\text { end. }\end{array}$ \\
\hline SIZE & The log of the market capitalization of equity over the previous calendar year, in thousands of dollars. \\
\hline LogAT & Natural log of total assets (AT). \\
\hline RET1-12 & Compounded gross returns for months t-12 through t- 1 . \\
\hline ILLIQ & $\begin{array}{l}\text { Following Amihud (2002), we construct the Illiq measure as the daily ratio of absolute stock return } \\
\text { to dollar volume. }\end{array}$ \\
\hline Mktrf & Market return minus return on the U.S. Treasury bond \\
\hline SMB & Return of a portfolio of small stocks minus the return of a portfolio of large stocks. \\
\hline HML & $\begin{array}{l}\text { Return on a portfolio of stocks with high book-to-market ratio, minus return on a portforlio of stocks } \\
\text { with low book-to-market ratio. }\end{array}$ \\
\hline UMD & $\begin{array}{l}\text { Return on a portfolio of stocks with a high past 12-month return, minus the return on a portfolio of } \\
\text { stocks with a low past } 12 \text {-month return. }\end{array}$ \\
\hline LIQ & Traded liquidity factor constructed by Pastor and Stambaugh (2003). \\
\hline EM & $\begin{array}{l}\text { The absolute value of abnormal accruals derived from performance-augmented discretionary accruals } \\
\text { model. This model is introduced by Kothari, Leone, and Wasley (2005). }\end{array}$ \\
\hline CI & $\begin{array}{l}\text { Following Titman, Wei and Xie (2004), we construct the measure of abnormal capital investment as } \\
\text { the ratio of CPAX/TOT_ASSET. }\end{array}$ \\
\hline E-index & The Entrenchment index of Bebchuck, Cohen and Ferrell (2009). \\
\hline G-Index & The governance index of Gompers, Ishii and Metrick (2003). \\
\hline Tobin's Q & $\begin{array}{l}\text { We define the Tobin's Q as the ratio of market value of assets and the book value of assets. Market } \\
\text { value of assets is defined as the difference between the sum of the book value of assets and the market } \\
\text { value of common stock and the sum of book value of common stock and balance sheet-deferred taxes. }\end{array}$ \\
\hline R\&D/Sales & The ratio of research and development expenditures to sales. \\
\hline ROA & The ratio of net income to total assets. \\
\hline Insider Ownership & The fraction of shares held by insders (CEO, CFO, CO, President). \\
\hline AGE & The first date of the companys total assets data in Compustat. \\
\hline CashFlow & $\begin{array}{l}\text { The sum of income before extraordinary items and depreciation and amortization, scaled by lagged } \\
\text { total assets. }\end{array}$ \\
\hline AssetGrowth & Changes in total assets scaled by lagged total assets. \\
\hline SaleGrowth & Changes in sales scaled by lagged sales. \\
\hline TotAccrual & $\begin{array}{l}\text { The difference between reported earnings and reported cash from operations. We compute it accord- } \\
\text { ing to Eq.(B.1). }\end{array}$ \\
\hline Leverage & The ratio of long term debt (dltt+dls) to total assets (at). \\
\hline Capx & The ratio of fixed assets (capxv) to total assets (at). \\
\hline FixedAsset & The ratio of PP\&E to total assets (at). \\
\hline YLD & The ratio of previous year's dividend to total asset. \\
\hline NASDUM & $\begin{array}{l}\text { A dummy variable equal to one if the firm traded on the NASDAQ Stock Market at the year of } \\
\text { trading data and zero otherwise. }\end{array}$ \\
\hline IOC & The sum of the top five institutional investors share ownership \\
\hline IOR & The institutional ownership ratio. \\
\hline WPS & $\begin{array}{l}\text { The dollar change in CEO wealth for a } 100 \text { percentage point change in firm value, scaled by annual } \\
\text { flow compensation. }\end{array}$ \\
\hline
\end{tabular}




\section{References}

Admati, A., \& Pfleiderer, P. (2009). The "Wall Street Walk" and Shareholder Activism: Exit as a Form of Voice. Review of Financial Studies, 22(7), 2645-2685.

Ahmed, A. S., Zhou, J., \& Lobo, G. J. (2006). Job Security and Income Smoothing: An Empirical Test of the Fudenberg and Tirole (1995) Model. Working Papaer.

Amihud, Y. (2002). Illiquidity and stock returns: cross-section and time-series effects. Journal of Financial Markets, 31-56.

Ang, A., Hodrick, R. J., Xing, Y., \& Zhang, X. (2006). The Cross-Section of Volatility and Expected Returns. The Journal of Finance, 61(1), 259-299.

Bebchuk, L. A., \& Cohen, A. (2005). The costs of entrenched boards. Journal of Financial Economics, 78(2), 409-433.

Bebchuk, L. A., Cohen, A., \& Ferrell, A. (2009). What Matters in Corporate Governance? Review of Financial Studies, 22(2), 783-827.

Bergstresser, D., \& Philippon, T. (2006). CEO incentives and earnings management. Journal of Financial Economics, 80, 511-529.

Bessembinder, H. (2003). Trade execution costs and market quality after decimalization. Journal of Financial and Quantitative Analysis, 38(4), 747-778.

Bharath, S., Jayaraman, S., \& Nagar, V. (2012). Exit as Governance: An Empirical Analysis. Journal of Finance Forthcoming.

Billett, M. T., Garfinkel, J. A., \& Jiang, Y. (2011). The influence of governance on investment: Evidence from a hazard model. Journal of Financial Economics, 102, 643-670.

Black, B. (1990). Shareholder passivity reexamined. Michigan Law Review, 89(3), 520-608.

Burns, N., \& Kedia, S. (2006). The impact of performance-based compensation on misreporting. Journal of Financial Economics, 79, 35-67.

Bushee, B. (1998). The influence of institutional investors on myopic R\&D investment behavior. Accounting Review, 305-333.

Carhart, M. M. (1997). On persistence in mutual fund performance. Journal of Finance, 52(1), $57-82$.

Chen, Harford, J., \& Li, K. (2007). Monitoring: Which institutions matter? Journal of Financial 
Economics, 86(2), 279-305.

Chen, \& Swan, P. (2012). CEO incentives and institutional trader monitoring are substitutes: Theory and evidence. Working Paper.

Cohen, D., Dey, A., \& Lys, T. (2008). Real and Accrual-Based Earnings Management in the Pre-and Post-Sarbanes-Oxley Periods. The Accounting Review, 83(3), 757-787.

Coles, J. L., Hertzel, M., \& Kalpathy, S. (2006). Earnings management around employee stock option reissues. Journal of Accounting and Economics, 173-200.

Cooper, R. W., \& Haltiwanger, J. C. (2006). On the nature of capital adjustment costs. The Review of Economic Studies, 611-633.

Cornett, M. M., Marcus, A. J., \& Tehranian, H. (2008). Corporate governance and pay-forperformance: The impact of earnings management. Journal of Financial Economics, 87, $357-373$.

Cronqvist, H., \& Fahlenbrach, R. (2009). Large shareholders and corporate policies. Review of Financial Studies, 3941-3976.

Cummins, J. G., Hassett, K. A., \& Oliner, S. D. (2006). Investment behavior, observable expectations, and internal funds. The American Economic Review, 796-810.

Edmans, A. (2009). Blockholder trading, market efficiency, and managerial myopia. Journal of Finance, 64(6), 2481-2513.

Edmans, A., Fang, V. W., \& Zur, E. (2013). The effect of liquidity on governance. Review of Financial Studies, 26(6), 1443-1482.

Edmans, A., Gabaix, X., \& Landier, A. (2009). A multiplicative model of optimal CEO incentives in market equilibrium. Review of Financial Studies, 4881-4917.

Edmans, A., \& Manso, G. (2011). Governance Through Trading and Intervention: A Theory of Multiple Blockholders. Review of Financial Studies, 24 (7), 23-95.

Efendi, J., Srivastava, A., \& Swanson, E. P. (2007). Why do corporate managers misstate financial statements? The role of option compensation and other factors. Journal of Financial Economics, 667-708.

Erickson, T., \& Whited, T. (2000). Measurement Error and the Relationship between Investment and q. Journal of Political Economy, 1027-1057.

Fama, E. F., \& French, K. R. (1993). Common risk factors in the returns on stocks and bonds. 
Journal of Financial Economics, 33(1), 3-56.

Fama, E. F., \& French, K. R. (1997). Industry costs of equity. Journal of Financial Economics, 43(2), 153-193.

Fama, E. F., \& MacBeth, J. D. (1973). Risk, return, and equilibrium: Empirical tests. Journal of Political Economy, 81(3), 607-636.

Furbine, C. H. (2003). Decimalization and market liquidity. Economic Perspectives, QIV, 2-12.

Gallagher, D., Gardner, P., \& Swan, P. (2012). Governance through trading: Institutional swing trades and subsequent firm performance. Journal of Financial and Quantitative Analysis Forthcoming.

Gaspar, J., Massa, M., \& Matos, P. (2005). Shareholder investment horizons and the market for corporate control. Journal of Financial Economics, 76(1), 135-165.

Gillan, S. L., \& Starks, L. T. (2000). Corporate governance proposals and shareholder activism: the role of institutional investors. Journal of Financial Economics, 57(2), 275 -305.

Gillan, S. L., \& Starks, L. T. (2007). The evolution of shareholder activism in the united states. Journal of Applied Corporate Finance, 19, 55-73.

Gompers, P., Ishii, J., \& Metrick, A. (2003). Corporate governance and equity prices. Quarterly Journal of Economics, 118, 107-155.

Gompers, P., \& Metrick, A. (2001). Institutional investors and equity prices. Quarterly Journal of Economics, 116(1), 229-259.

Gong, G., Louis, H., \& Sun, A. X. (2008). Earnings management and firm performance following open-market repurchases. The Journal of Finance, 947-986.

Goyenko, R. Y., Holden, C. W., \& Trzcinka, C. A. (2009). Do liquidity measures measure liquidity? Journal of Financial Economics, 92(2), 153-181.

Hartzell, J., \& Starks, L. (2003). Institutional investors and executive compensation. Journal of Finance, 58(6), 2351-2374.

Hazarika, S., Karpoff, J. M., \& Nahata, R. (2012). Internal corporate governance, CEO turnover, and earnings management. Journal of Financial Economics, 104, 44-69.

Hirshleifer, D., Hou, K., Teoh, S. H., \& Zhang, Y. (2004). Do investors overvalue firms with bloated balance sheets? Journal of Accounting and Economics, 38(0), 297-331.

Jensen, M. (1986). Agency costs of free cash flow, corporate finance, and takeovers. American 
Economic Review, 76(2), 323-329.

Kaplan, S. N., \& Zingales, L. (1997). Do investment-cash flow sensitivities provide useful measures of financing constraints? Quarterly Journal of Economics, 169-215.

Karpoff, J. M., Lee, D. S., \& Martin, G. S. (2008). The cost to firms of cooking the books. Journal of Financial and Quantitative Analysis, 43(03), 581-611.

Karpoff, J. M., \& Lou, X. (2010). Short sellers and financial misconduct. The Journal of Finance, 65, 1879-1913.

Karpoff, J. M., Scott Lee, D., \& Martin, G. S. (2008). The consequences to managers for financial misrepresentation. Journal of Financial Economics, 88, 193-215.

Kim, E., \& Lu, Y. (2011). CEO ownership, external governance, and risk-taking. Journal of Financial Economics.

Klein, A. (2002). Audit committee, board of director characteristics, and earnings management. Journal of Accounting and Economics, 33, 375-400.

Klein, A., \& Zur, E. (2009). Entrepreneurial shareholder activism: Hedge funds and other private investors. Journal of Finance, 64(1), 187-229.

Klein, A., \& Zur, E. (2011). The impact of hedge fund activism on the target firm's existing bondholders. Review of Financial Studies, 24(5), 1735-1771.

Kothari, S., Leone, A. J., \& Wasley, C. E. (2005). Performance matched discretionary accrual measures. Journal of Accounting and Economics, 39(1), 163 - 197.

Lakonishok, J., Shleifer, A., \& Vishny, R. (1994). Contrarian investment, extrapolation, and risk. Journal of Finance, 49(5), 1541-1578.

La Porta, R., Silanes, F. Lopez-de, \& Shleifer, A. (1999). Corporate ownership around the world. Journal of Finance, 54, 471-517.

Lowenstein, L. (1989). What's wrong with wall street? short-term gain and the absentee shareholder. Addison-Wesley, Reading, MA.

McCahery, J. A., Starks, L. T., \& Sautner, Z. (2010). Behind the scenes: The corporate governance preferences of institutional investors. Working Paper.

Meyer, B. (1990). Unemployement insurance and unemployement spells. Econometrica, 58, 757782.

Nofsinger, J. R., \& Sias, R. W. (1999). Herding and feedback trading by institutional and individual 
investors. Journal of Finance, 54(6), 2263-2295.

Pastor, L., \& Stambaugh, R. F. (2003). Liquidity risk and expected stock returns. Journal of Political Economy, 111, 642-685.

Petersen, M. A. (2009). Estimating standard errors in finance panel data sets: Comparing approaches. Review of Financial Studies, 435-480.

Richardson, S. (2006). Over-investment of free cash flow. Review of Accounting Studies, 11(2), 159-189.

Shin, H.-H., \& Stulz, R. M. (2000). Firm value, risk, and growth opportunities. NBER Working Paper No.7808.

Sloan, R. G. (1996). Do stock prices fully reflect information in accruals and cash flows about future earnings? The Accounting Review, 71(3), 289-315.

Teoh, S. H., Welch, I., \& Wong, T. (1998). Earnings management and the underperformance of seasoned equity offerings. Journal of Financial Economics, 63-99.

Titman, S., Wei, K., \& Xie, F. (2004). Capital investments and stock returns. Journal of Financial and Quantitative Analysis, 39(4), 677-700.

Whited, T. (2006). External finance constraints and the intertemporal pattern of intermittent investment. Journal of Financial Economics, 81(3), 467-502.

Woidtke, T. (2002). Agents watching agents?: evidence from pension fund ownership and firm value. Journal of Financial Economics, 63(1), 99-131.

Yan, X. S., \& Zhang, Z. (2009). Institutional investors and equity returns: Are short-term institutions better informed? Review of Financial Studies, 22, 893-924. 
Table 1. Description Statistics

This table presents the summary statistics of variables. RPI represents the log of the annual sum of the absolute value of quarterly changes in institutional holdings, aggregated across all institutions of firm. These data are derived from $13 \mathrm{~F}$ quarterly holdings data. CI is the measure of abnormal capital investment. Following Titman, Wei and Xie (2004), we construct the measure of CI as the ratio of current year's capital investment and three previous average of firm's capital investment, and then minus 1. EM is the absolute value of abnormal accruals derived from performance-augmented discretionary accruals model. This model is introduced by Kothari, Leone, and Wasley (2005). SIZE is the log of market capitalization. LogAT is the $\log$ of total assets (at). BM is the ratio of the book value of equity divided by the market value of equity, as of the previous year end. LogAT is the log of total assets. AGE is calculated based on the first date of the companys total assets data in Compustat. Leverage is the ratio of long term debt (dltt+dls) to total assets (at). CashFlow is the sum of income before extraordinary items and depreciation and amortization, scaled by lagged total assets. ROA is the ratio of net income to total assets. We define the Tobin's Q as the ratio of market value of assets and the book value of assets. Market value of assets is defined as the difference between the sum of the book value of assets and the market value of common stock and the sum of book value of common stock and balance sheet-deferred taxes. $R \& D /$ Sales is the ratio of research and development expenditures to sales. Insider Ownership is the fraction of shares held by insiders (CEO, CFO, CO, President). E- Index is the Entrenchment index of Bebchuck, Cohen and Ferrell (2009). G-Index is the corporate governance provision index of Gompers, Ishii and Metrick (2003). FixedAsset is the ratio of fixed assets (PP\&E) to total assets (at). Capx is the ratio of capital expenditure and total assets. SaleGrowth is the changes in sales scaled by lagged sales. ILLIQ is the daily ratio of absolute stock return to dollar volume, following Amihud (2002). AssetGrowth is the changes in total assets scaled by lagged total assets. IOC is the measure of institutional ownership concentration, as the sum of the top five institutional investors share ownership. IOR is the measure of institutional ownership ratio. WPS is the measure of managers' scaled wealth-performance sensitivity, which measures the dollar change in CEO wealth for a 100 percentage point change in firm value, divided by annual flow compensation. The detailed definitions of these variables are reported in Appendix C.

\begin{tabular}{|c|c|c|c|c|c|c|}
\hline Variable & $\mathrm{N}$ & Mean & Std. Dev. & $25 \%$ & $50 \%$ & $75 \%$ \\
\hline RPI & 114,372 & 14.1900 & 2.7595 & 12.3627 & 14.4200 & 16.3263 \\
\hline $\mathrm{CI}$ & 72,879 & 0.0260 & 0.7696 & -0.4434 & -0.1236 & 0.2580 \\
\hline EM & 101,399 & 0.0715 & 0.0893 & 0.0203 & 0.0474 & 0.0960 \\
\hline SIZE & 110,141 & 4.7858 & 1.9639 & 3.3437 & 4.7090 & 6.2073 \\
\hline BM & 110,141 & 0.7555 & 1.0287 & 0.3077 & 0.5664 & 0.9559 \\
\hline $\mathrm{AGE}$ & 110,311 & 14.6907 & 12.2882 & 5.0000 & 11.0000 & 21.0000 \\
\hline Leverage & 109,878 & 0.2859 & 0.9922 & 0.0368 & 0.2041 & 0.3891 \\
\hline LogAT & 63,297 & 5.4227 & 1.8260 & 4.0634 & 5.3621 & 6.7321 \\
\hline CashFlow & 109,410 & 0.0161 & 0.9413 & 0.0152 & 0.0821 & 0.1420 \\
\hline ROA & 110,311 & -0.0385 & 0.9665 & -0.0299 & 0.0384 & 0.0893 \\
\hline Tobin's Q & 87,632 & 1.8287 & 1.9374 & 1.0100 & 1.3100 & 1.9600 \\
\hline R\&D/Sales & 48,475 & 0.4823 & 7.8663 & 0.0063 & 0.0341 & 0.1118 \\
\hline InsiderOwnership & 57,664 & 0.0833 & 0.6231 & 0.0047 & 0.0189 & 0.0753 \\
\hline E-index & 20,304 & 2.3936 & 1.3146 & 1.0000 & 2.0000 & 3.0000 \\
\hline G-Index & 19,824 & 8.9243 & 2.7612 & 7.0000 & 9.0000 & 11.0000 \\
\hline Capx & 93,476 & 0.0696 & 0.0824 & 0.0218 & 0.0462 & 0.0875 \\
\hline FixedAsset & 89,159 & 0.3003 & 0.3826 & 0.0000 & 0.1012 & 0.5261 \\
\hline SaleGrowth & 93,921 & 0.1749 & 0.4187 & -0.0093 & 0.0950 & 0.2453 \\
\hline ILLIQ & 114,070 & 0.2247 & 0.9159 & 0.0006 & 0.0059 & 0.0703 \\
\hline AssetGrowth & 115,448 & 0.1941 & 0.8967 & -0.0277 & 0.0736 & 0.2200 \\
\hline $\mathrm{IOC}$ & 99,374 & 0.1423 & 0.0981 & 0.0666 & 0.1304 & 0.2020 \\
\hline IOR & 93,480 & 0.3517 & 0.2781 & 0.1087 & 0.2984 & 0.5532 \\
\hline WPS & 28,826 & 36.8639 & 125.6790 & 3.2001 & 6.9379 & 17.8303 \\
\hline
\end{tabular}


Table 2. Sorting Analysis

This table presents average monthly returns for stocks with low, median and high institutional trades Average return numbers are in percentages. Each month, we divide our sample of firms into three RPI portfolios: low (bottom 30\%), median (median 40\%) and high (top 30\%). RPI is measured by the absolute value of the summation of changes in quarterly snapshots of institutional holdings, by using $13 \mathrm{~F}$ quarterly holdings data. We then compute the value-weighted average monthly return of the three institutional trades portfolios using individual stock returns in the next year. We also calculate the return difference for subsamples of firms sorted on size, book-to-market ratio, past 12 months returns.

\begin{tabular}{|c|c|c|c|c|c|}
\hline & \multicolumn{4}{|c|}{ Average Monthly Return (\%) } & \multirow{3}{*}{$\begin{array}{r}\text { t-Statistics } \\
\text { High-Low }\end{array}$} \\
\hline & \multicolumn{3}{|c|}{ RPI } & \multirow[b]{2}{*}{ High-Low } & \\
\hline & High & Median & Low & & \\
\hline \multicolumn{6}{|c|}{ Panel A: All of samples } \\
\hline All Stocks & 1.1168 & 0.7530 & 0.6121 & 0.5046 & 2.78 \\
\hline \multicolumn{6}{|c|}{ Panel B: By Size } \\
\hline 1 & 1.7390 & 1.0702 & 0.8670 & 0.8720 & 4.90 \\
\hline 2 & 1.5067 & 0.8798 & 0.4597 & 1.0469 & 5.81 \\
\hline 3 & 1.2218 & 1.0178 & 0.6614 & 0.5604 & 4.57 \\
\hline \multicolumn{6}{|c|}{ Panel C: By Book-to-Market } \\
\hline 1 & 0.9857 & 0.4055 & -0.2272 & 1.2129 & 4.64 \\
\hline 2 & 1.1978 & 0.8481 & 0.8027 & 0.3950 & 2.08 \\
\hline 3 & 1.1850 & 1.1548 & 1.0027 & 0.1822 & 0.83 \\
\hline \multicolumn{6}{|c|}{ Panel D: By Past Returns } \\
\hline 1 & 0.7242 & 0.1882 & 0.0466 & 0.6776 & 2.42 \\
\hline 2 & 0.9680 & 0.7723 & 0.7415 & 0.2266 & 1.35 \\
\hline 3 & 1.2118 & 0.7207 & 0.6655 & 0.5463 & 2.44 \\
\hline
\end{tabular}


Table 3. Risk-adjusted return of long-short strategy based on the RPI

This table presents the profitability of a trading strategy that longs stock with high RPI and shorts stocks with low RPI. Stocks are ranked based on the RPI, the summation of absolute value of institutional trading volume during four quarters. Stocks are considered to have high RPI if the sum of absolute value of trading volume falls into top decile of distribution. Stocks are considered to have low RPI if the sum of absolute value of trading volume falls into bottom decile of distribution. Both the long and short positions are value weighted, and held for 12 month after portfolio formation. Portfolios are rebalanced annually. The resulting time-series returns on the long-short portfolio are regressed on different risk factors, and the results are reported. t-values are in parentheses. ${ }^{*}, * *, * *$ indicate statistical significance at the $10 \%, 5 \%$, and $1 \%$ level, respectively.

\begin{tabular}{|c|c|c|c|c|}
\hline & $\begin{array}{l}\text { Model 1: } \\
\text { CAPM }\end{array}$ & $\begin{array}{cl} & \text { Model 2: } \\
\text { FF } & \text { Three-Factor }\end{array}$ & $\begin{array}{c}\text { Model 3: } \\
\text { Carhart Four-Factor }\end{array}$ & $\begin{array}{c}\text { Model 4: } \\
\text { PS Liquidity }\end{array}$ \\
\hline \multicolumn{5}{|c|}{ Long High RPI Stocks, Short Low RPI Stocks } \\
\hline$\overline{\text { Alpha (\%) }}$ & $0.577^{* *}$ & $0.615^{* * *}$ & $0.658^{* * *}$ & $0.660^{* * *}$ \\
\hline \multirow{3}{*}{ Mkt-rf } & $(2.49)$ & $(2.92)$ & $(3.07)$ & $(3.04)$ \\
\hline & $0.251^{* * *}$ & $0.341^{* * *}$ & $0.328 * * *$ & $0.328^{* * *}$ \\
\hline & $(5.03)$ & $(7.16)$ & $(6.66)$ & $(6.65)$ \\
\hline \multirow[t]{2}{*}{ SMB } & & $-0.621 * * *$ & $-0.618 * * *$ & $-0.618 * * *$ \\
\hline & & $(8.98)$ & $(8.93)$ & $(8.91)$ \\
\hline \multirow[t]{2}{*}{ HML } & & -0.018 & -0.034 & -0.034 \\
\hline & & $(0.25)$ & $(0.45)$ & $(0.46)$ \\
\hline \multirow[t]{2}{*}{ UMD } & & & -0.048 & -0.048 \\
\hline & & & (1.05) & $(1.05)$ \\
\hline \multirow[t]{2}{*}{ LIQ } & & & & -0.004 \\
\hline & & & & $(0.08)$ \\
\hline
\end{tabular}


Table 4. Fama-Macbeth regression of the RPI and Stock Returns

This table presents the average coefficients and time series t value for cross sectional regressions for each month from January 1980 to December 2011. The dependent variable is the stock return for month t. Reward-punishment intensity (RPI) is equal to the natural log of the absolute value of the summation of changes in quarterly snapshots of institutional holdings, by using $13 \mathrm{~F}$ quarterly holdings data in the previous year. SIZE is the log of market capitalization. BM is the ratio of the book value of equity divided by the market value of equity, as of the previous year end. SaleGrowth is the changes in sales scaled by lagged sales. AssetGrowth is the changes in total assets scaled by lagged total assets. TotAccrual is the difference between reported earnings and reported cash from operations. NASDUM is a dummy variable equal to one if the firm traded on the NASDAQ Stock Market at the year of trading data and zero otherwise. RET1-12 is the compounded gross returns for months t-12 through t-1. YLD is the ratio of previous year's dividend to total asset. IOR is the measure of institutional ownership ratio. IOC is the measure of institutional ownership concentration, as the sum of the top five institutional investors' share ownership. ILLIQ is the daily ratio of absolute stock return to dollar volume, following Amihud (2002). E-index is the entrenchment index of Bebchuck, Cohen and Ferrell (2009). G-Index is the governance index of Gompers, Ishii and Metrick (2003). The number of observations varies depending on data availability. Detailed definitions for the variables are provided in Appendix C. All results are adjusted for Newey-West for 12 lags. Constant values are omitted. $t$-values are in parentheses. $* * *$, and $* * *$ indicate statistical significance at the $10 \%, 5 \%$, and $1 \%$ level, respectively.

\begin{tabular}{|c|c|c|c|c|c|c|c|c|c|c|c|}
\hline Variable & (1) & (2) & (3) & (4) & (5) & (6) & (7) & (8) & (9) & (10) & (11) \\
\hline \multirow[t]{2}{*}{$\overline{\mathrm{RP}}$} & 0.0028 & 0.0028 & 0.0028 & 0.003 & 0.0031 & 0.0031 & 0.003 & 0.0032 & 0.0037 & 0.0065 & 0.0071 \\
\hline & $(5.87)^{* * *}$ & $(5.89) * * *$ & $(6.00)^{* * *}$ & $(5.35) * * *$ & $(5.56)^{* * *}$ & $(5.56)^{* * *}$ & $(5.41)^{* * *}$ & $(5.59)^{* * *}$ & $(5.83) * * *$ & $(7.17)^{* * *}$ & $(5.55) * * *$ \\
\hline \multirow[t]{2}{*}{ SIZE } & -0.005 & -0.005 & -0.0049 & -0.0056 & -0.0056 & -0.0056 & -0.0054 & -0.0065 & -0.0066 & -0.0072 & -0.0067 \\
\hline & $(5.02)^{* * *}$ & $(4.99)^{* * *}$ & $(5.01)^{* * *}$ & $(5.07) * * *$ & $(5.55)^{* * *}$ & $(5.55)^{* * *}$ & $(5.4)^{* * *}$ & $(5.63) * * *$ & $(5.93) * * *$ & $(5.05) * * *$ & $(4.14)^{* * *}$ \\
\hline \multirow[t]{2}{*}{$\mathrm{BM}$} & 0.0021 & 0.0017 & 0.0017 & 0.0012 & 0.0012 & 0.0013 & 0.0013 & 0.0012 & 0.0012 & -0.0002 & 0.0001 \\
\hline & $(2.56)^{* *}$ & $(2.08)^{* *}$ & $(2.13)^{* *}$ & (1.28) & $(1$ & $(1.7)^{*}$ & $(1.72)^{*}$ & 8) & 52) & $(0.27)$ & $(0.08)$ \\
\hline \multirow[t]{2}{*}{ AssetGrowth } & & -0.0039 & -0.0038 & -0.0029 & -0.0029 & -0.0031 & -0.0028 & -0.0029 & -0.003 & -0.0040 & -0.0040 \\
\hline & & $(6.83)^{* * *}$ & $(7.2)^{* * *}$ & $(5.49)^{* * *}$ & $(5.58) * * *$ & $(5.84)^{* * *}$ & $(6.00)^{* * *}$ & $(5.8) * * *$ & $(5.89)^{* * *}$ & $(2.53)^{* *}$ & $(2.71)^{* * *}$ \\
\hline SaleGrowth & & & $\begin{array}{r}0.0003 \\
(1.59)\end{array}$ & $\begin{array}{r}0.0004 \\
(1.33)\end{array}$ & $\begin{array}{r}0.0004 \\
(1.34)\end{array}$ & $\begin{array}{r}0.0004 \\
(1.31)\end{array}$ & $\begin{array}{r}0.0004 \\
(1.32)\end{array}$ & $\begin{array}{c}0.0004 \\
(1.27)\end{array}$ & $\begin{array}{r}0.0005 \\
(1.47)\end{array}$ & $\begin{array}{r}0.0020 \\
(0.81)\end{array}$ & $\begin{array}{r}0.0008 \\
(0.56)\end{array}$ \\
\hline \multirow[t]{2}{*}{ TotAccrual } & & & & -0.0131 & -0.0132 & -0.0135 & -0.0125 & -0.0125 & -0.0127 & -0.0244 & -0.0199 \\
\hline & & & & $(2.65)^{* * *}$ & $(2.74)^{* * *}$ & $(2.83)^{* * *}$ & $(2.77)^{* * *}$ & $(2.72)^{* * *}$ & $(2.76)^{* * *}$ & $(3.92)^{* * *}$ & $(2.78)^{* * *}$ \\
\hline NASDUM & & & & & $\begin{array}{r}-0.0007 \\
(0.40)\end{array}$ & $\begin{array}{r}-0.0006 \\
(0.40)\end{array}$ & $\begin{array}{r}-0.0006 \\
(0.39)\end{array}$ & $\begin{array}{r}-0.0008 \\
(0.53)\end{array}$ & $\begin{array}{r}-0.0008 \\
(0.52)\end{array}$ & $\begin{array}{r}-0.0001 \\
(0.05)\end{array}$ & $\begin{array}{r}0.0001 \\
(0.07)\end{array}$ \\
\hline YLD & & & & & & $\begin{array}{r}-3.873 \\
(0.40)\end{array}$ & $\begin{array}{r}-3.9794 \\
(0.44)\end{array}$ & $\begin{array}{r}-1.4307 \\
(0.15)\end{array}$ & $\begin{array}{r}-1.0007 \\
(0.02)\end{array}$ & $\begin{array}{r}-0.0000 \\
(0.06)\end{array}$ & $\begin{array}{r}0.0000 \\
(0.21)\end{array}$ \\
\hline RET1-12 & & & & & & & $\begin{array}{r}-0.0192 \\
(0.58)\end{array}$ & $\begin{array}{r}-0.0216 \\
(0.98)\end{array}$ & $\begin{array}{r}-0.0144 \\
(1.01)\end{array}$ & $\begin{array}{r}-0.0024 \\
(0.86)\end{array}$ & $\begin{array}{r}-0.0048 \\
(1.07)\end{array}$ \\
\hline ILLIQ & & & & & & & & 0.0054 & 0.0044 & 0.0020 & 0.0015 \\
\hline & & & & & & & & $(4.91$ & & $(2.82)$ & \\
\hline IOR & & & & & & & & & -0.0068 & -0.0185 & -0.0174 \\
\hline & & & & & & & & & )** & $(7.04)^{* * *}$ & $(6.48)^{* * *}$ \\
\hline G-Index & & & & & & & & & & $\begin{array}{r}-0.0001 \\
(0.64)\end{array}$ & \\
\hline E-Index & & & & & & & & & & & $\begin{array}{r}-0.0004 \\
(1.29)\end{array}$ \\
\hline dj_Rsquare & 158 & & & & & & & & & & \\
\hline No. of obs & $1,164,511$ & $1,164,511$ & $1,155,013$ & 905,522 & 905,522 & 898,146 & 898,146 & 897,944 & 897,764 & 177,367 & 196,333 \\
\hline
\end{tabular}


Table 5. Panel regression of the RPI and Stock Returns

This table presents panel regressions of firm's subsequent monthly return on reward-punishment intensity (RPI) and other control variables. The dependent variable is the stock return for month t. RPI is equal to the natural $\log$ of the absolute value of the summation of changes in quarterly snapshots of institutional holdings, by using $13 \mathrm{~F}$ quarterly holdings data in the previous year. SIZE is the log of market capitalization. $\mathrm{BM}$ is the ratio of the book value of equity divided by the market value of equity, as of the previous year end. SaleGrowth is the changes in sales scaled by lagged sales. AssetGrowth is the changes in total assets scaled by lagged total assets. TotAccrual is the difference between reported earnings and reported cash from operations. NASDUM is a dummy variable equal to one if the firm traded on the NASDAQ Stock Market at the year of trading data and zero otherwise. YLD is the ratio of previous year's dividend to total asset. RET1-12 is the compounded gross returns for months t-12 through t-1. IOR is the measure of institutional ownership ratio. IOC is the measure of institutional ownership concentration, as the sum of the top five institutional investors' share ownership. ILLIQ is the daily ratio of absolute stock return to dollar volume, following Amihud (2002). E-index is the entrenchment index of Bebchuck, Cohen and Ferrell (2009). G-Index is the governance index of Gompers, Ishii and Metrick (2003). The number of observations varies depending on data availability. Detailed definitions for the variables are provided in Appendix C. Constant is also omitted. Following Petersen (2009), standards errors are adjusted for two-way cluster adjusted for firm and month. $t$-values are in parentheses. $* * *$, and $* * *$ indicate statistical significance at the $10 \%, 5 \%$, and $1 \%$ level, respectively.

\begin{tabular}{|c|c|c|c|c|c|c|c|c|c|c|c|}
\hline ariable & (1) & (2) & (3) & (4) & (5) & (6) & $(7)$ & (8) & $(9)$ & $(10)$ & (11) \\
\hline RPI & 0.0032 & 0.0031 & 0.0031 & 0.0031 & 0.0031 & 0.0031 & 0.0031 & 0.0032 & 0.0037 & 0.0074 & 0.0085 \\
\hline & $(5.78)^{* * *}$ & $(5.76) * * *$ & $(5.75) * * *$ & $(5.00)^{* * *}$ & $(5.10) * * *$ & $(5.15)^{* * *}$ & $(5.17) * * *$ & $(5.11)^{* * *}$ & $7.04)^{* * *}$ & $6.62) * * *$ & $6.92)^{* * *}$ \\
\hline SIZE & -0.0058 & -0.0058 & -0.0057 & -0.0061 & -0.0062 & -0.0062 & -0.0062 & -0.0065 & -0.0069 & -0.0075 & -0.0075 \\
\hline & $(7.07)^{* * *}$ & $(7.00)^{* * *}$ & $6.92)^{* * *}$ & $(6.54)^{* * *}$ & $(6.65)^{* * *}$ & $(6.63)^{* * *}$ & $(6.72)^{* * *}$ & $(6.28)^{* * *}$ & $(5.76)^{* * *}$ & $5.38) * * *$ & $4.98) * * *$ \\
\hline $\mathrm{BM}$ & $\begin{array}{c}0.0014 \\
(1.68)^{*}\end{array}$ & $\begin{array}{r}0.0013 \\
(1.60)\end{array}$ & $\begin{array}{r}0.0013 \\
(1.59)\end{array}$ & $\begin{array}{r}0.0009 \\
(1.20)\end{array}$ & $\begin{array}{r}0.0008 \\
(1.18)\end{array}$ & $\begin{array}{r}0.0008 \\
(1.16)\end{array}$ & $\begin{array}{r}0.0008 \\
(1.18)\end{array}$ & & $\begin{array}{r}0.0008 \\
(1.15)\end{array}$ & $\begin{array}{r}0.0000 \\
(0.02)\end{array}$ & $\begin{array}{r}0.0003 \\
(0.20)\end{array}$ \\
\hline AssetGrowth & & -0.0027 & -0.0029 & -0.0029 & -0.0028 & -0.0030 & -0.0029 & -0.0030 & -0.0029 & -0.0051 & -0.0045 \\
\hline & & $(3.25)$ & $(3.32)^{* * *}$ & $(2.86)^{* * *}$ & $(2.93) * * *$ & $(2.87)^{* * *}$ & $(2.86) * * *$ & $(2.87)^{* * *}$ & $(2.98)^{* * *}$ & $(2.98)^{* * *}$ & $(2.30)^{* *}$ \\
\hline SaleGrowth & & & $\begin{array}{r}-0.0000 \\
(0.95)\end{array}$ & $\begin{array}{r}-0.0000 \\
(1.25)\end{array}$ & $\begin{array}{r}-0.0000 \\
(1.25)\end{array}$ & $\begin{array}{r}-0.0000 \\
(0.95)\end{array}$ & $\begin{array}{r}-0.0000 \\
(0.95)\end{array}$ & $\begin{array}{r}-0.0000 \\
(0.87)\end{array}$ & $\begin{array}{r}-0.0000 \\
(0.90)\end{array}$ & $\begin{array}{r}-0.0004 \\
(0.99)\end{array}$ & $\begin{array}{l}-0.0001 \\
(1.76)^{*}\end{array}$ \\
\hline TotalAccrual & & & & $\begin{array}{r}-0.0190 \\
(2.88)^{* * *}\end{array}$ & $\begin{array}{r}-0.0191 \\
(2.95)^{* * *}\end{array}$ & $\begin{array}{r}-0.0193 \\
(3.06)^{* * *}\end{array}$ & $\begin{array}{r}-0.0193 \\
(3.06)^{* * *}\end{array}$ & $\begin{array}{r}-0.0191 \\
(3.04)^{* * *}\end{array}$ & $\begin{array}{r}-0.0192 \\
(3.02)^{* * *}\end{array}$ & $\begin{array}{r}-0 . \\
(3.24\end{array}$ & $\begin{array}{r}-0.0316 \\
(2.98)^{* * *}\end{array}$ \\
\hline NASDUM & & & & & $\begin{array}{r}-0.0013 \\
(0.54)\end{array}$ & $\begin{array}{r}-0.0012 \\
(0.52)\end{array}$ & $\begin{array}{r}-0.0012 \\
(0.52)\end{array}$ & $\begin{array}{r}-0.0013 \\
(0.56)\end{array}$ & $\begin{array}{r}-0.0008 \\
(0.35)\end{array}$ & $\begin{array}{r}-0.0014 \\
(0.79)\end{array}$ & $\begin{array}{r}-0.0003 \\
(0.16)\end{array}$ \\
\hline YLD & & & & & & & & & $\begin{array}{r}0 . \\
(2.65\end{array}$ & & $\begin{array}{r}0.0000 \\
(0.79)\end{array}$ \\
\hline RET1-12 & & & & & & & $\begin{array}{r}-0.0002 \\
(0.56)\end{array}$ & $\begin{array}{r}-0.0000 \\
(18.26)^{* * *}\end{array}$ & $\begin{array}{r}-0.0000 \\
23.56)^{* * *}\end{array}$ & $\begin{array}{r}-0.0000 \\
6.67)^{* * *}\end{array}$ & $\begin{array}{r}-0.0000 \\
4.30)^{* * *}\end{array}$ \\
\hline ILLIQ & & & & & & & & & & $\begin{array}{r}-0.0003 \\
(0.42)\end{array}$ & $\begin{array}{r}-0.0007 \\
(0.78)\end{array}$ \\
\hline IOR & & & & & & & & & $\begin{array}{r}-0.0054 \\
(0.70)\end{array}$ & $\begin{array}{r}-0.0247 \\
(2.35)^{* *}\end{array}$ & $\begin{array}{r}-0.0241 \\
(2.41)^{* *}\end{array}$ \\
\hline G-Index & & & & & & & & & & $\begin{array}{r}-0.0000 \\
(0.18)\end{array}$ & \\
\hline E-Index & & & & & & & & & & & $\begin{array}{r}-0.0004 \\
(1.30)\end{array}$ \\
\hline dj_Rsquare & 0.0013 & 0.0014 & & & & & & & & & \\
\hline No. of obs 1 & $1,164,511$ & $1,164,511$ & 155,013 & 905,522 & 905,522 & 898,146 & 898,146 & 897,944 & 897,764 & 177,247 & 196,333 \\
\hline
\end{tabular}


Table 6. RPI and Subsequent Tobin's Q

This table presents panel regressions of firm's subsequent Tobin's Q on reward-punishment intensity (RPI) and other control variables. Tobin's Q is defined as the ratio of book value of assets minus book value of equity plus market value of equity to the book value of total assets. RPI is equal to the log of the absolute value of the summation of changes in quarterly snapshots of institutional holdings, by using $13 \mathrm{~F}$ quarterly holdings data in the previous year. SIZE is the natural logarithm of total assets. ROA is the ratio of net income to total assets. $R \& D /$ Sales is the ratio of $\mathrm{R} \& \mathrm{D}$ expenditures to total sales. Insider ownership is equal to the fraction of shares held by insiders, such as CEO, CFO, CO as well as president. AGE is computed based on the first date of the companys total assets data in Compustat. IOR represents the institutional ownership ratio. E-Index is the Entrenchment index of Bebchuck, Cohen and Ferrell (2009). G-Index is the corporate governance provision index of Gompers, Ishii and Metrick (2003). Industry dummies are also used to control for industry effects, while their coefficients are omitted. Constant is also omitted. The number of observations varies depending on data availability. Detailed definitions for the variables are provided in Appendix C. Following Petersen (2009), standards errors are adjusted for two-way cluster adjusted for firm and year. $t$-values are in parentheses. ${ }^{*},{ }^{* *}$, and ${ }^{* * *}$ indicate statistical significance at the $10 \%, 5 \%$, and $1 \%$ level, respectively.

\begin{tabular}{|c|c|c|c|c|c|c|c|c|}
\hline Variable & (1) & $(2)$ & (3) & (4) & $(5)$ & (6) & (7) & (8) \\
\hline \multirow[t]{2}{*}{ RPI } & 0.3019 & 0.3044 & 0.3053 & 0.3051 & 0.3247 & 0.3252 & 0.4071 & 0.5240 \\
\hline & $(15.08) * * *$ & $(15.08)^{* * *}$ & $(14.96)^{* * *}$ & $(14.96)^{* * *}$ & $(14.84)^{* * *}$ & $(14.85)^{* * *}$ & $(9.93) * * *$ & $(11.72)^{* * *}$ \\
\hline \multirow[t]{2}{*}{ SIZE } & -0.4482 & -0.4560 & -0.4326 & -0.4325 & -0.4217 & -0.4220 & -0.3604 & -0.4203 \\
\hline & $(15.14)^{* * *}$ & $(15.02)^{* * *}$ & $(17.27)^{* * *}$ & $(17.25)^{* * *}$ & $(16.63)^{* * *}$ & $(16.63)^{* * *}$ & $(12.11)^{* * *}$ & $(12.86)^{* * *}$ \\
\hline \multirow[t]{2}{*}{ AGE } & & 0.0019 & 0.0024 & 0.0024 & 0.0025 & 0.0025 & -0.0025 & -0.0003 \\
\hline & & $(1.19)$ & $(1.51)$ & $(1.52)$ & $(1.61)$ & $(1.66)^{*}$ & $(1.64)$ & $(0.19)$ \\
\hline \multirow[t]{2}{*}{$\mathrm{ROA}$} & & & -0.8045 & -0.7930 & -0.7764 & -0.7787 & 2.7174 & 2.3642 \\
\hline & & & $(2.65) * * *$ & $(2.58) * * *$ & $(2.55)^{* *}$ & $(2.55)^{* *}$ & $(5.48) * * *$ & $(5.43) * * *$ \\
\hline R\&D/sales & & & & 0.0019 & 0.0019 & 0.0020 & -0.0029 & 0.0174 \\
\hline & & & & (1.13) & $(1.13)$ & $(1.13)$ & $(0.40)$ & $(2.59)^{* * *}$ \\
\hline \multirow[t]{2}{*}{ IOR } & & & & & -0.2908 & -0.2822 & -0.9570 & -0.7363 \\
\hline & & & & & $(1.91)^{*}$ & $(1.87)^{*}$ & $(5.06)^{* * *}$ & $(4.18)^{* * *}$ \\
\hline \multirow[t]{2}{*}{ InsiderOwnership } & & & & & & 0.0841 & & \\
\hline & & & & & & $(2.02)^{* *}$ & & \\
\hline \multirow[t]{2}{*}{$(\text { InsiderOwnership })^{2}$} & & & & & & -0.0016 & & \\
\hline & & & & & & $(2.37)^{* *}$ & & \\
\hline E-Index & & & & & & & $\begin{array}{l}-0.0179 \\
(1.07) * *\end{array}$ & \\
\hline \multirow{2}{*}{ G-Index } & & & & & & & & -0.0616 \\
\hline & & & & & & & & $(3.46)^{* * *}$ \\
\hline Ind. Dummies & Yes & Yes & Yes & Yes & Yes & Yes & Yes & Yes \\
\hline No. Observations & 63252 & 63252 & 63252 & 63252 & 63252 & 63240 & 15008 & 17631 \\
\hline R-square & 0.1441 & 0.1442 & 0.1508 & 0.1509 & 0.1515 & 0.1516 & 0.2386 & 0.3006 \\
\hline
\end{tabular}


Table 7. Semi-parametric Hazard Model estimates: effects of Reward-Punishment Intensity The sample period is 1980-2011. Following Whited (2006) and Billet et al. (2011), we include firms whose real assets are below the $33^{\text {rd }}$ percentile of the real assets in the first year that the firm appears in sample. CashFlow is the net income and depreciation divided by total assets. SalesGrowth is the growth rate of sales. E-index is the entrenchment index of Bebchuck, Cohen and Ferrell (2009). G-Index is the governance index of Gompers, Ishii and Metrick (2003). The rows labeled by year hazard include estimates of baseline hazard, and the different number indicates the number of year since the last spike. A spike is defined as a investment rate exceeds a threshold, and the thresholds are defined in terms of 2, 2.5, and 3 times the firm median investment rate. P-values are in parentheses under the parameter estimates. ${ }^{*}, * *$, and $* * *$ indicate statistical significance at the $10 \%, 5 \%$, and $1 \%$ level, respectively.

\begin{tabular}{|c|c|c|c|c|c|c|}
\hline & \multicolumn{2}{|c|}{2 times } & \multicolumn{2}{|c|}{2.5 times } & \multicolumn{2}{|c|}{3 times } \\
\hline & $(1)$ & $(2)$ & $(3)$ & $(4)$ & $(5)$ & $(6)$ \\
\hline \multirow[t]{2}{*}{ RPI } & -0.2897 & -0.2969 & -0.2832 & -0.3008 & -0.2834 & -0.2941 \\
\hline & $(0.00) * * *$ & $(0.00)^{* * *}$ & $(0.00)^{* * *}$ & $(0.00) * * *$ & $(0.00) * * *$ & $(0.00)^{* * *}$ \\
\hline \multirow[t]{2}{*}{ CashFlow } & -0.0061 & -0.0603 & -0.0062 & -0.0042 & -0.0005 & -0.0401 \\
\hline & $(0.08)^{*}$ & $(0.28)$ & $(0.06)^{*}$ & $(0.22)$ & $(0.07)^{*}$ & $(0.11)^{* * *}$ \\
\hline \multirow[t]{2}{*}{ SalesGrowth } & 0.3620 & 0.5157 & 0.3539 & 0.5450 & 0.3470 & 0.5190 \\
\hline & $(0.00)^{* * *}$ & $(0.00)^{* * *}$ & $(0.00) * * *$ & $(0.00) * * *$ & $(0.00) * * *$ & $(0.00)^{* * *}$ \\
\hline \multirow[t]{2}{*}{ TotalAssets } & 0.0006 & 0.0004 & 0.0004 & -0.0001 & 0.0006 & 0.0001 \\
\hline & $(0.00)^{* * *}$ & $(0.35)$ & $(0.24)$ & $(0.92)$ & $(0.07)^{*}$ & $(0.75)$ \\
\hline \multirow[t]{2}{*}{ Leverage } & 0.1458 & 0.3065 & 0.2252 & 0.3919 & 0.2660 & 0.3368 \\
\hline & $(0.35)$ & $(0.17)$ & $(0.22)$ & $(0.17)$ & $(0.14)$ & $(0.21)$ \\
\hline \multirow[t]{2}{*}{ G-Index } & & 0.0053 & & 0.0158 & & 0.0202 \\
\hline & & $(0.88)$ & & $(0.51)$ & & $(0.29)$ \\
\hline \multirow[t]{2}{*}{1 year hazard } & -5.9989 & -6.2834 & -5.8291 & -6.1459 & -5.6875 & -5.9418 \\
\hline & $(0.00)^{* * *}$ & $(0.00)^{* * *}$ & $(0.00)^{* * *}$ & $(0.00) * * *$ & $(0.00) * * *$ & $(0.00)^{* * *}$ \\
\hline \multirow[t]{2}{*}{2 year hazard } & -4.4433 & -5.4773 & -4.5642 & -6.0314 & -4.5354 & -5.8274 \\
\hline & $(0.00)^{* * *}$ & $(0.00)^{* * *}$ & $(0.00)^{* * *}$ & $(0.00) * * *$ & $(0.00) * * *$ & $(0.00)^{* * *}$ \\
\hline \multirow[t]{2}{*}{3 year hazard } & -2.3281 & -2.6823 & -2.3623 & -2.8291 & -2.4854 & -2.9116 \\
\hline & $(0.00) * * *$ & $(0.00) * * *$ & $(0.00) * * *$ & $(0.00) * * *$ & $(0.00) * * *$ & $(0.00)^{* * *}$ \\
\hline \multirow[t]{2}{*}{4 year hazard } & -1.8826 & -2.1058 & -1.9925 & -2.2390 & -2.1410 & -2.2584 \\
\hline & $(0.00) * * *$ & $(0.00)^{* * *}$ & $(0.00)^{* * *}$ & $(0.00) * * *$ & $(0.00) * * *$ & $(0.00)^{* * *}$ \\
\hline \multirow[t]{2}{*}{5 year hazard } & -1.6839 & -1.8224 & -1.8497 & -1.9662 & -1.9192 & -2.0712 \\
\hline & $(0.00)^{* * *}$ & $(0.00)^{* * *}$ & $(0.00)^{* * *}$ & $(0.00)^{* * *}$ & $(0.00)^{* * *}$ & $(0.00)^{* * *}$ \\
\hline \multirow[t]{2}{*}{6 year hazard } & -1.2818 & -1.5951 & -1.3670 & -1.6048 & -1.4308 & -1.6273 \\
\hline & $(0.00) * * *$ & $(0.00)^{* * *}$ & $(0.00)^{* * *}$ & $(0.00) * * *$ & $(0.00) * * *$ & $(0.00)^{* * *}$ \\
\hline \multirow[t]{2}{*}{7 year hazard } & -0.9859 & -1.1271 & -1.0799 & -1.1617 & -1.2460 & -1.2783 \\
\hline & $(0.00)^{* * *}$ & $(0.00)^{* * *}$ & $(0.00)^{* * *}$ & $(0.00)^{* * *}$ & $(0.00) * * *$ & $(0.00)^{* * *}$ \\
\hline \multirow[t]{2}{*}{8 year hazard } & -0.9281 & -1.1034 & -0.9789 & -1.2222 & -1.0360 & -1.2460 \\
\hline & $(0.00)^{* * *}$ & $(0.00)^{* * *}$ & $(0.00)^{* * *}$ & $(0.00)^{* * *}$ & $(0.00) * * *$ & $(0.00)^{* * *}$ \\
\hline \multirow[t]{2}{*}{9 year hazard } & -0.6420 & -0.6839 & -0.7087 & -0.6932 & -0.7551 & -0.7758 \\
\hline & $(0.00)^{* * *}$ & $(0.00)^{* * *}$ & $(0.00) * * *$ & $(0.00) * * *$ & $(0.00)^{* * *}$ & $(0.00)^{* * *}$ \\
\hline \multirow[t]{2}{*}{10 year hazard } & -0.5363 & -0.6678 & -0.5849 & -0.6694 & -0.6452 & -0.7228 \\
\hline & $(0.00)^{* * *}$ & $(0.00)^{* * *}$ & $(0.00)^{* * *}$ & $(0.00)^{* * *}$ & $(0.00) * * *$ & $(0.00)^{* * *}$ \\
\hline log likelihood & -5899.52 & -3229.92 & -5825.55 & -2788.63 & -5290.72 & -2414.82 \\
\hline
\end{tabular}


Table 8. RPI and Abnormal Capital Investment

This table presents panel regressions of firm's subsequent abnormal capital investment on reward-punishment intensity (RPI) and other control variables. Abnormal Capital Investment (CI) is defined following Titman et. al. (2004). RPI is equal to the natural $\log$ of the absolute value of the summation of changes in quarterly snapshots of institutional holdings, by using $13 \mathrm{~F}$ quarterly holdings data in the previous year. SIZE is the $\log$ of market capitalization. Leverage is equal to the ratio of long term debt to total assets. FixedAsset is the ratio of fixed assets to total assets. CashFlow is equal to the sum of income before extraordinary items and depreciation and amortization. ROA is the ratio of net income to total assets. SaleGrowth is the changes in sales scaled by lagged sales. We define the Tobin's Q as the ratio of market value of assets and the book value of assets. Market value of assets is defined as the difference between the sum of the book value of assets and the market value of common stock and the sum of book value of common stock and balance sheet-deferred taxes. E-index is the entrenchment index of Bebchuck, Cohen and Ferrell (2009). G-Index is the governance index of Gompers, Ishii and Metrick (2003). Industry dummies are also used to control for industry effects (Fama French 48 industries), while their coefficients are omitted. Constant is also omitted. Detailed definitions for the variables are provided in Appendix C. Following Petersen (2009), standards errors are adjusted for two-way cluster adjusted for firm and year. $t$-values are in parentheses. ${ }^{*}, * *$, and ${ }^{* * *}$ indicate statistical significance at the $10 \%, 5 \%$, and $1 \%$ level, respectively.

\begin{tabular}{|c|c|c|c|c|c|c|c|c|c|c|}
\hline Variable & (1) & (2) & (3) & (4) & $\overline{(5)}$ & $\overline{(6)}$ & $\overline{(7)}$ & $\overline{(8)}$ & $\overline{(10)}$ & $\overline{(11)}$ \\
\hline \multirow[t]{2}{*}{ RPI } & -0.0613 & -0.0505 & -0.0509 & -0.0514 & -0.0506 & -0.0502 & -0.0486 & -0.0462 & -0.0171 & -0.0160 \\
\hline & $(5.51)^{* * *}$ & $(4.59) * * *$ & $(4.66) * * *$ & $(4.73)^{* * *}$ & $(4.61) * * *$ & $(4.58) * * *$ & $(4.64)^{* * *}$ & $(4.39) * * *$ & $(1.79)^{*}$ & (1.77)* \\
\hline \multirow[t]{2}{*}{ Size } & 0.0360 & 0.0055 & 0.0053 & 0.0055 & 0.0028 & 0.0018 & 0.0009 & -0.0049 & -0.0033 & -0.0046 \\
\hline & $(4.63)^{* * *}$ & (0.69) & (0.68) & $(0.71)$ & $(0.34)$ & $(0.23)$ & $(0.12)$ & $(0.63)$ & $(0.43)$ & $(0.53)$ \\
\hline \multirow[t]{2}{*}{$\mathrm{BM}$} & & -0.1284 & -0.1216 & -0.1218 & -0.1221 & -0.1227 & -0.1072 & -0.0921 & -0.1354 & -0.1404 \\
\hline & & $(8.52)^{* * *}$ & $(8.13)^{* * *}$ & $(8.22)^{* * *}$ & $(8.16)^{* * *}$ & $(8.14)^{* * *}$ & $(7.90)^{* * *}$ & $(7.25)^{* * *}$ & $(7.56)^{* * *}$ & $(6.13)^{* * *}$ \\
\hline \multirow[t]{2}{*}{ Leverage } & & & -0.3943 & -0.3872 & -0.3805 & -0.3773 & -0.3762 & -0.3347 & -0.1564 & -0.1759 \\
\hline & & & $(6.18)^{* * *}$ & $(6.21)^{* * *}$ & $(6.06)^{* * *}$ & $(5.97)^{* * *}$ & $(6.03) * * *$ & $(5.52)^{* * *}$ & $(3.09)^{* * *}$ & $(2.96)^{* * *}$ \\
\hline \multirow[t]{2}{*}{ FixedAsset } & & & & -0.0579 & -0.0614 & -0.0572 & -0.0440 & -0.0438 & -0.0060 & -0.0011 \\
\hline & & & & $(1.83)^{*}$ & $(1.98)^{* *}$ & $(1.88)^{*}$ & $(1.50)$ & & $(0.24)$ & $(0.03)$ \\
\hline \multirow[t]{2}{*}{ CashFlow } & & & & & 0.1066 & -0.1423 & -0.1058 & -0.0745 & -0.6087 & -0.6776 \\
\hline & & & & & $(2.13)^{* *}$ & $(0.70)$ & $(0.55)$ & $(0.38)$ & $(2.32)^{* *}$ & $(2.03)^{* *}$ \\
\hline \multirow[t]{2}{*}{ ROA } & & & & & & 0.2509 & 0.2300 & 0.2361 & 0.8215 & 0.9573 \\
\hline & & & & & & $(1.34)$ & $(1.28)$ & $(1.28)$ & $(3.66)^{* * *}$ & $(3.47)^{* * *}$ \\
\hline \multirow{2}{*}{ SaleGROWTH } & & & & & & & 0.1769 & 0.1611 & 0.2382 & 0.2121 \\
\hline & & & & & & & $(3.94) * * *$ & $(3.50) * * *$ & $(5.52)^{* * *}$ & $(4.04)^{* * *}$ \\
\hline Tobin's Q & & & & & & & & 0.0279 & -0.0057 & -0.0082 \\
\hline & & & & & & & & $(2.88) * * *$ & $(0.70)$ & $(0.55)$ \\
\hline E-Index & & & & & & & & & 0.0051 & \\
\hline & & & & & & & & & $(1.25)$ & \\
\hline G-Index & & & & & & & & & & $\begin{array}{r}-0.0036 \\
(1.19)\end{array}$ \\
\hline Ind. Du & & & & & & S & $\mathrm{Ye}$ & $\mathrm{Y}$ & Yes & Yes \\
\hline & & & & & & 99 & & & 0.0455 & 0.0520 \\
\hline No. Observations & 67585 & 67585 & 67357 & 67357 & 67082 & 67082 & 66756 & 66756 & 12078 & 6017 \\
\hline
\end{tabular}


Table 9. RPI and Earnings Management

This table reports the effect of reward-punishment intensity (RPI) on the subsequent firm's earnings management. RPI is measured as annual sum of the absolute value of quarterly change in institutional holdings, aggregated across all institutions trading shares in the firm. Following Hazarika, Karpoff and Nahata (2012), we measure earnings management as the absolute value of abnormal accruals derived from performanceaugmented discretionary accruals model. This model is introduced by Kothari, Leone, and Wasley (2005). SIZE is the log of market capitalization. BM is the ratio of the book value of equity divided by the market value of equity, as of the previous year end. AGE is calculated based on the first date of the company's total assets data in Compustat. Leverage is the ratio of long term debt (dltt+dls) to total assets (at). Capx is the ratio of capxv and total assets (at). CashFlow is the sum of income before extraordinary items and depreciation and amortization, scaled by lagged total assets. ROA is the ratio of net income to total assets. E-index is the entrenchment index of Bebchuck, Cohen and Ferrell (2009). G-Index is the governance index of Gompers, Ishii and Metrick (2003). The number of observations varies depending on data availability. Detailed definitions for the variables are provided in Appendix C. Constant is also omitted. Following Petersen (2009), standards errors are adjusted for two-way cluster adjusted for firm and year. t-values are in parentheses. ${ }^{*}, * *$, and ${ }^{* * *}$ indicate statistical significance at the $10 \%, 5 \%$, and $1 \%$ level, respectively.

\begin{tabular}{|c|c|c|c|c|c|c|c|c|}
\hline \multicolumn{9}{|c|}{ Dependent Variable: Subsequent Absolute Earnings Management } \\
\hline Variable & (1) & $(2)$ & $(3)$ & $(4)$ & $(5)$ & (6) & $(7)$ & $(8)$ \\
\hline \multirow[t]{2}{*}{ RPI } & -0.0024 & -0.0016 & -0.0018 & -0.0018 & -0.0018 & -0.0018 & -0.0014 & -0.0016 \\
\hline & $(5.13) * * *$ & $(3.80) * * *$ & $(4.22)^{* * *}$ & $(4.23)^{* * *}$ & $(4.17)^{* * *}$ & $(4.21)^{* * *}$ & $(1.91)^{*}$ & $(1.84)^{*}$ \\
\hline \multirow[t]{2}{*}{ SIZE } & -0.0044 & -0.0062 & -0.0050 & -0.0049 & -0.0049 & -0.0050 & -0.0034 & -0.0033 \\
\hline & $(5.86) * * *$ & $(8.00) * * *$ & $(6.19) * * *$ & $(6.15)^{* * *}$ & $(6.30)^{* * *}$ & $(6.43)^{* * *}$ & $(3.58)^{* * *}$ & $(3.37)^{* * *}$ \\
\hline \multirow[t]{2}{*}{$\mathrm{BM}$} & & -0.0071 & -0.0064 & -0.0064 & -0.0064 & -0.0064 & -0.0076 & -0.0085 \\
\hline & & $(3.89) * * *$ & $(3.90) * * *$ & $(3.90) * * *$ & $(3.90) * * *$ & $(3.93) * * *$ & $(5.04)^{* * *}$ & $(5.06)^{* * *}$ \\
\hline \multirow[t]{2}{*}{ AGE } & & & -0.0004 & -0.0004 & -0.0004 & -0.0004 & -0.0031 & -0.0034 \\
\hline & & & $(8.57)^{* * *}$ & $(8.55) * * *$ & $(8.49)^{* * *}$ & $(8.50) * * *$ & $(3.40)^{* * *}$ & $(3.09)^{* * *}$ \\
\hline \multirow[t]{2}{*}{ Capx } & & & & -0.0001 & -0.0002 & -0.0008 & 0.0280 & 0.0160 \\
\hline & & & & $(0.27)$ & $(0.64)$ & $(2.30)^{* *}$ & $(2.71)^{* * *}$ & $(1.52)$ \\
\hline \multirow[t]{2}{*}{ Cash Flow } & & & & & -0.0016 & 0.0083 & 0.0769 & 0.0909 \\
\hline & & & & & $(2.86)^{* * *}$ & $(2.19)^{* *}$ & $(2.67)^{* * *}$ & $(2.86)^{* * *}$ \\
\hline \multirow[t]{2}{*}{ ROA } & & & & & & -0.0099 & -0.0850 & -0.0989 \\
\hline & & & & & & $(2.98) * * *$ & $(3.08) * * *$ & $(3.36)^{* * *}$ \\
\hline E-Index & & & & & & & -0.0003 & \\
\hline & & & & & & & $(0.63)$ & \\
\hline G-Index & & & & & & & & 0.0001 \\
\hline & & & & & & & & $(0.49)$ \\
\hline Ind. Dummies & Yes & Yes & Yes & Yes & Yes & Yes & Yes & Yes \\
\hline No. of Obs & 101,237 & 101,237 & 101,237 & 101,032 & 100,984 & 100,984 & 15385 & 12790 \\
\hline R-squared & 0.0834 & 0.0884 & 0.0909 & 0.0909 & 0.0912 & 0.0916 & 0.0922 & 0.0898 \\
\hline
\end{tabular}




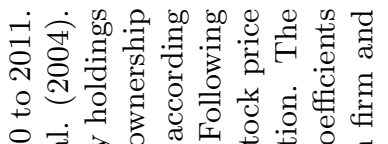

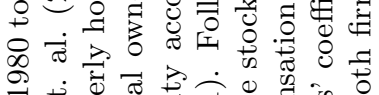

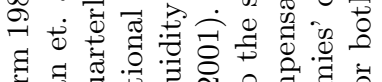



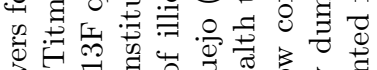

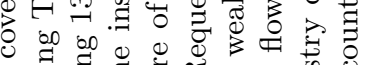

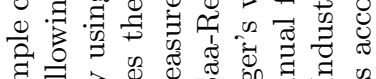

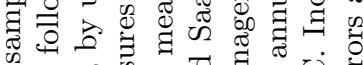

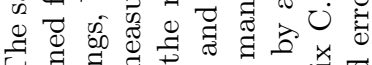

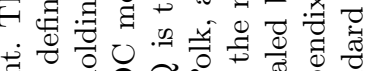

范 0

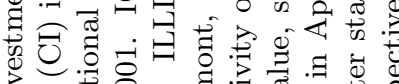

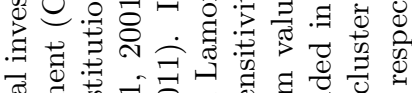

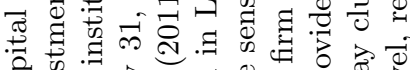

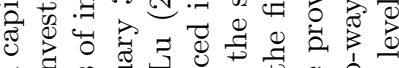

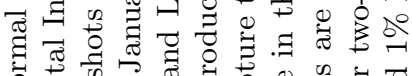

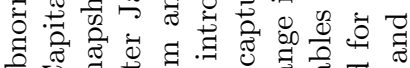

సิ

궁



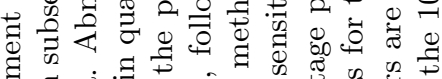

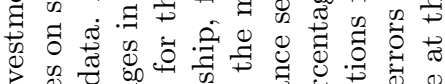
论

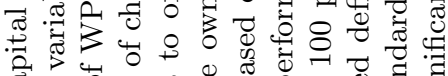
赵 ర人



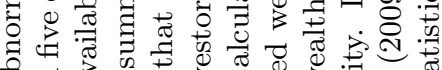

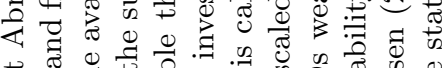

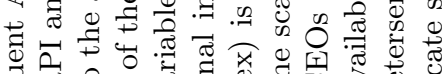

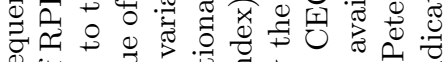



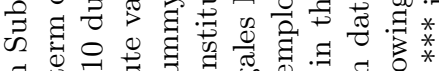

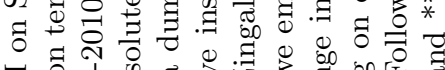

둥ำ

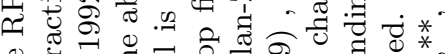

\&

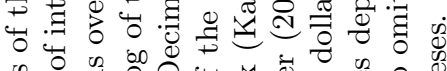

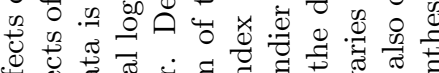

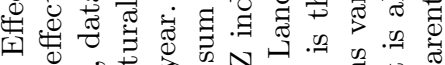

\%

च

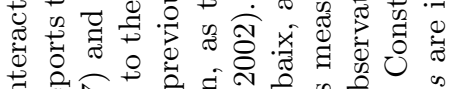

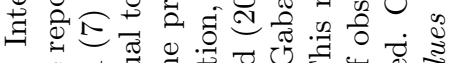

$\circ \stackrel{0}{0} \exists$

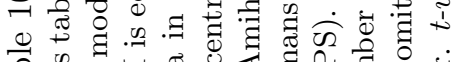

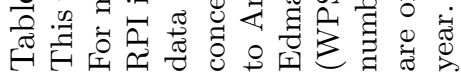

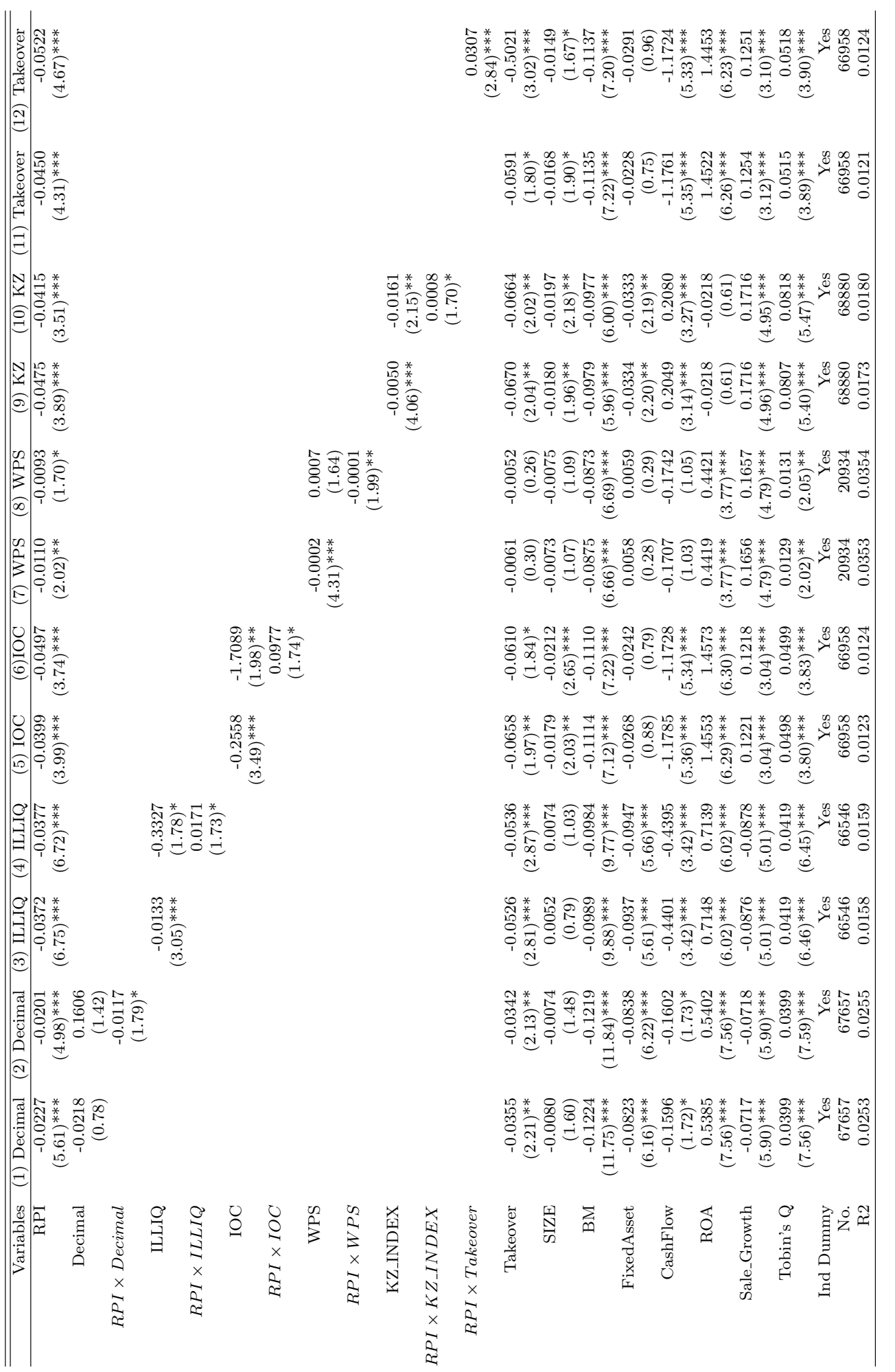


Table 11. Interaction Effects of the RPI on Subsequent Earnings Management

This table reports the effects of interaction term of RPI and 4 others variables on subsequent earnings management. Following Hazarika, Karpoff and Nahata (2012), we measure earnings management as the absolute value of abnormal accruals derived from performance-augmented discretionary accruals model. This model is introduced by Kothari, Leone, and Wasley (2005). RPI is equal to the natural log of the absolute value of the summation of changes in quarterly snapshots of institutional holdings, by using $13 \mathrm{~F}$ quarterly holdings data in the previous year. The sample covers from 1980 to 2011. For model (7) and (8), data is over 1992-2010 due to the availability of WPS data. Decimal is a dummy variable that equals to one for the period after January 31, 2001. IOC measures the institutional ownership concentration, as the uses the sum of the top five institutional investors share ownership, following Kim and Lu (2011). ILLIQ is the measure of illiquidity according to Amihud (2002). Following Edmans, Gabaix, and Landier (2009), we employ the scaled wealth-performance sensitivity to capture the sensitivity of the manager's wealth to the stock price (WPS). This measure is the dollar change in the CEOs wealth for a 100 percentage point change in the firm value, scaled by annual flow compensation. The number of observations varies depending on data availability. Detailed definitions for the variables are provided in Appendix C. Industry dummies are also used to control for industry effects, while their coefficients are omitted. Constant is also omitted. Following Petersen (2009), standards errors are adjusted for two-way cluster standard errors accounted for both firm and year. $t$-values are in parentheses. ${ }^{*}, *$, and $* * *$ indicate statistical significance at the $10 \%, 5 \%$, and $1 \%$ level, respectively.

\begin{tabular}{|c|c|c|c|c|c|c|c|c|}
\hline & (1) Decimal & (2) Decimal & (3) ILLIQ & (4) ILLIQ & (5) $\mathrm{IOC}$ & (6)IOC & (7) WPS & (8) WPS \\
\hline \multirow[t]{2}{*}{ RPI } & -0.0017 & -0.0016 & -0.0017 & -0.0018 & -0.0008 & -0.0012 & -0.0022 & -0.0020 \\
\hline & $(4.70)^{* * *}$ & $(4.06)^{* * *}$ & $(4.14)^{* * *}$ & $(4.23) * * *$ & $(2.24)^{* *}$ & $(2.79)^{* * *}$ & $(1.74)^{*}$ & $(1.68)^{*}$ \\
\hline Decimal & -0.0108 & 0.0042 & & & & & & \\
\hline \multirow{2}{*}{$R P I \times$ Decimal } & $(8.42)$ & $\begin{array}{r}(0.11) \\
-0.0010\end{array}$ & & & & & & \\
\hline & & $(2.60)^{* * *}$ & & & & & & \\
\hline \multirow[t]{2}{*}{ ILLIQ } & & & 0.0031 & -0.0308 & & & & \\
\hline & & & $(2.36)^{* *}$ & $(1.83)^{*}$ & & & & \\
\hline \multirow[t]{2}{*}{$R P I \times I L L I Q$} & & & & 0.0018 & & & & \\
\hline & & & & $(2.03)^{* *}$ & & & & \\
\hline \multirow[t]{2}{*}{ IOC } & & & & & -0.0608 & -0.1444 & & \\
\hline & & & & & $(11.60)^{* * *}$ & $(3.40)^{* * *}$ & & \\
\hline$R P I \times I O C$ & & & & & & 0.0056 & & \\
\hline \multirow[t]{2}{*}{ WPS } & & & & & & & 0.0106 & 0.354 \\
\hline & & & & & & & $(3.77)^{* * *}$ & $(2.06)^{* *}$ \\
\hline \multirow[t]{2}{*}{$R P I \times W P S$} & & & & & & & & -0.0174 \\
\hline & & & & & & & & $(2.01)^{* *}$ \\
\hline \multirow[t]{2}{*}{ SIZE } & -0.0041 & -0.0040 & -0.0054 & -0.0052 & -0.0045 & -0.0048 & 0.0004 & 0.0002 \\
\hline & $(6.01)^{* * *}$ & $(5.89)^{* * *}$ & $(6.28) * * *$ & $(6.20) * * *$ & $(6.62)^{* * *}$ & $(7.09)^{* * *}$ & $(0.34)$ & $(0.20)$ \\
\hline \multirow[t]{2}{*}{$\mathrm{BM}$} & -0.0071 & -0.0071 & -0.0075 & -0.0075 & -0.0068 & -0.0067 & -0.0046 & -0.0046 \\
\hline & $(6.12)^{* * *}$ & $(6.15)^{* * *}$ & $(6.79) * * *$ & $(6.79) * * *$ & $(6.46)^{* * *}$ & $(6.48)^{* * *}$ & $(3.41)^{* * *}$ & $(3.45)^{* * *}$ \\
\hline \multirow[t]{2}{*}{ AGE } & -0.0072 & -0.0073 & -0.0078 & -0.0078 & -0.0074 & -0.0073 & -0.0059 & -0.0058 \\
\hline & $(12.38)^{* * *}$ & $(12.51)^{* * *}$ & $(14.12)^{* * *}$ & $(14.03)^{* * *}$ & $(13.44)^{* * *}$ & $(13.18)^{* * *}$ & $(4.16)^{* * *}$ & $(4.23)^{* * *}$ \\
\hline \multirow[t]{2}{*}{ Capx } & -0.0015 & -0.0015 & -0.0007 & -0.0007 & -0.0012 & -0.0011 & 0.0457 & 0.0454 \\
\hline & $(1.89)^{*}$ & $(1.93)^{*}$ & $(0.86)$ & $(0.86)$ & $(1.35)$ & $(1.22)$ & $(4.20)^{* * *}$ & $(4.14)^{* * *}$ \\
\hline \multirow[t]{2}{*}{ CashFlow } & 0.0065 & 0.0064 & 0.0068 & 0.0068 & 0.0066 & 0.0066 & 0.0268 & 0.0272 \\
\hline & $(1.88)^{*}$ & $(1.88)^{*}$ & $(1.79)^{*}$ & $(1.79)^{*}$ & $(1.86)^{*}$ & $(1.84)^{*}$ & $(1.05)$ & (1.07) \\
\hline \multirow{2}{*}{ ROA } & -0.0082 & -0.0081 & -0.0083 & -0.0083 & -0.0081 & -0.0081 & -0.0519 & -0.0521 \\
\hline & $(2.73)^{* * *}$ & $(2.72)^{* * *}$ & $(2.46)^{* *}$ & $(2.47)^{* *}$ & $(2.57)^{* *}$ & $(2.53)^{* *}$ & $(2.21)^{* *}$ & $(2.21)^{* *}$ \\
\hline Ind Dummy & Yes & Yes & Yes & Yes & Yes & Yes & Yes & Yes \\
\hline No. & 95155 & 95155 & 95892 & 95892 & 95155 & 95155 & 23830 & 23830 \\
\hline R2 & 0.0961 & 0.0963 & 0.0947 & 0.0947 & 0.0965 & 0.0966 & 0.0786 & 0.0795 \\
\hline
\end{tabular}


Table 12. Subsample analysis of the RPI and the subsequent Tobin's Q, stock returns, Tobin's Q, CI, EM This table presents the relationship between the subsequent Tobin's Q, monthly stock returns, CI, and EM and RPI for subsample firms with changes in total institutional ownership ratio below the median of the year $(\triangle I O R)$. A firm is included in this test if its change in institutional ownership ratio below the median of changes in institutional ownership ratio of all firms in the year. Column 1 presents the profitability of a trading strategy that longs stock with high RPI and shorts stocks with low RPI. Stocks are ranked based on the value of RPI into 10 groups. Stocks are considered to have low RPI if the value of RPI falls into bottom decile distribution. Stocks are considered to have high RPI if the value of RPI falls falls into top decile of distribution. Both the long and short positions are value weighted, and held for 12 month after portfolio formation. Portfolios are annually rebalanced. The resulting time-series returns on the long-short portfolio are regressed on different risk factors, and the results are reported. Column 2 uses the subsequent Tobin's Q as the dependent variable, and includes firm size (log of total asset), book-to-market ratio, roa, age, R\&D expenditures, and institutional ownership ratio as control variables. Column 3 uses the monthly stock returns in the following year as the dependent variable, and includes firm size (log of market capital lizatoin), book-to-market ratio, book-to-market ratio, asset growth, sale growth, total accrual, exchange dummy, dividend yield, prior stock returns (1-12 months), Amihud illiquidity measure, and institutional ownership ratio as control variables. Column 4 utilizes the following abnormal capital investment (CI) as dependent variable. We include firm size (log of market capitalization), book-to-market ratio, roa, fixed asset ratio, cash flow, leverage ratio, sales growth, and Tobin's Q as control variables. Column 5 uses the following earnings management as dependent variable. We include firm size (log of market capitalization), book-to-market ratio, roa, age, fixed asset ratio, and cash flow as control variables. All regressions include industry dummies. For Column 2-5, following Petersen (2009), standards errors are adjusted for two-way cluster adjusted for firm and month. t-values are in parentheses. $t$-values are in parentheses. ${ }^{*}, * *$, and ${ }^{* * *}$ indicate statistical significance at the $10 \%, 5 \%$, and $1 \%$ level, respectively.

\begin{tabular}{|c|c|c|c|c|c|}
\hline & (1) Alpha & (2) Tobin's Q & (3) Stock Returns & (4) CI & (5) EM \\
\hline Alpha (\%) & $\begin{array}{c}0.503^{* *} \\
(2.30)\end{array}$ & & & & \\
\hline Mkt-rf & $\begin{array}{c}0.356^{* * * *} \\
(7.21)\end{array}$ & & & & \\
\hline SMB & $\begin{array}{c}-0.598^{* * *} \\
(8.58)\end{array}$ & & & & \\
\hline HML & $\begin{array}{r}-0.06) \\
-0.066 \\
(0.88)\end{array}$ & & & & \\
\hline UMD & $\begin{array}{c}-0.130^{* * *} \\
(2.86)\end{array}$ & & & & \\
\hline LIQ & $\begin{array}{c}0.137^{* *} \\
(2.50)\end{array}$ & & & & \\
\hline RPI & & $\begin{array}{c}0.2264 \\
(9.13)^{* * *}\end{array}$ & $\begin{array}{c}0.0043 \\
(5.78) * * *\end{array}$ & $\begin{array}{c}-0.0647 \\
(4.02)^{* * *}\end{array}$ & $\begin{array}{c}-0.0014 \\
(3.68)^{* * *}\end{array}$ \\
\hline SIZE & & $\begin{array}{c}-0.3227 \\
(11.05)^{* * *}\end{array}$ & $\begin{array}{c}-0.0082 \\
(5.68) * * *\end{array}$ & $\begin{array}{c}-0.0054 \\
(0.39)\end{array}$ & $\begin{array}{l}-0.0047 \\
(6.85)^{* * *}\end{array}$ \\
\hline $\mathrm{BM}$ & & & $\begin{array}{c}0.0004 \\
(0.67)\end{array}$ & $\begin{array}{c}-0.0492 \\
(3.92)^{* * *}\end{array}$ & $\begin{array}{l}-0.0049 \\
(6.94) * * *\end{array}$ \\
\hline ROA & & $\begin{array}{l}-0.7627 \\
(2.14)^{* *}\end{array}$ & & $\begin{array}{c}0.1711 \\
(1.02)\end{array}$ & $\begin{array}{l}-0.0270 \\
(2.18)^{* *}\end{array}$ \\
\hline AGE & & $\begin{array}{l}0.0207 \\
(0.62)\end{array}$ & & $\begin{array}{c}0.1148 \\
(2.36)^{* *}\end{array}$ & -0.0060 \\
\hline R\&DSales & & $\begin{array}{l}0.0001 \\
(0.05)\end{array}$ & & & \\
\hline IOR & & $\begin{array}{c}-0.0645 \\
(0.31)\end{array}$ & $\begin{array}{c}-0.0055 \\
(0.50)\end{array}$ & & \\
\hline AssetGrowth & & & $\begin{array}{l}-0.0031 \\
(2.31)^{* *}\end{array}$ & & \\
\hline SaleGrowth & & & $\begin{array}{c}-0.0000 \\
(0.58)\end{array}$ & & \\
\hline TotAccrual & & & $\begin{array}{l}-0.0211 \\
(2.46)^{* *}\end{array}$ & & \\
\hline NASDUM & & & $\begin{array}{c}-0.0006 \\
(0.33)\end{array}$ & & \\
\hline YLD & & & $\begin{array}{c}0.0001 \\
(3.12)^{* * *}\end{array}$ & & \\
\hline PriorRET & & & $\begin{array}{c}-0.0035 \\
(0.96)\end{array}$ & & \\
\hline ILLIQ & & & $\begin{array}{c}0.0005 \\
(0.51)\end{array}$ & & \\
\hline Cash Flow & & & & $\begin{array}{c}-0.0668 \\
(0.32)\end{array}$ & $\begin{array}{l}0.0161 \\
(1.25)\end{array}$ \\
\hline Leverage & & & & $\begin{array}{l}-0.5268 \\
(2.51)^{* *}\end{array}$ & $\begin{array}{l}-0.0032 \\
(1.73)^{*}\end{array}$ \\
\hline Sale_Growth & & & & $\begin{array}{c}-0.0000 \\
(0.49)\end{array}$ & \\
\hline Tobin's Q & & & & $\begin{array}{c}0.0388 \\
(3.22)^{* * *}\end{array}$ & \\
\hline Fixed Asset & & & & $\begin{array}{l}-0.2397 \\
(2.61)^{* * *}\end{array}$ & \\
\hline Capx & & & & & $\begin{array}{c}0.0012 \\
(0.26)\end{array}$ \\
\hline Ind Dummies & & Y & Y & Y & Y \\
\hline Obs & & 27,850 & 300,083 & 32729 & 38,554 \\
\hline $\mathrm{R} 2$ & & 0.1141 & 0.0032 & 0.0070 & 0.0781 \\
\hline
\end{tabular}


Table 13. Instrumental variable regressions for RPI and Subsequent Tobin's Q, CI, and EM

This table reports the second stage's results of two-stage-least-square regression results of the impact of RPI on subsequent firm value, abnormal capital investments, and earnings management. We utilize the mean of RPI of all firms in the same state, same industry, and same year, excluding firm i's own RPI as IV for RPI, denoted as RPI_SYI $(-i)$. In the first stage, we regress the RPI on RPI_SYI(- $i$ ) and other control variables, including firm size, book-to-market ratio, return on assets, firm's age, R\&D expenditure scaled by sales, institutional ownership ratio, fixed asset ratio, cash flow, leverage ratio, the growth of sales, and firm value. All regressions control for industryand year- fixed effects. Robust errors are clustered at the firm level and adjusted for heteroscedasticity. We do not tabulate the first stage's results for brevity. In the second stage, the variable of interest is the estimated value of RPI (IV(RPI_SYI(-i)). The dependent variables in model (1), model (2), and model (3) are Tobin's Q in the following year. We include firm size (log of total asset), book-to-market ratio, roa, age, R\&D expenditures, institutional ownership ratio, G-Index, and E-Index as control variables. The dependent variable in model (4), model (5), and model (6) are abnormal capital investments(CI) in the following year. We include firm size (log of market capitalization), bookto-market ratio, roa, fixed asset ratio, cash flow, leverage ratio, sales growth, Tobin's Q , G-Index, and E-Index as control variables. The dependent variable in model (7), model (8), and model (9) are Earnings Management (EM) in the subsequent year. We include firm size (log of market capitalization), book-to-market ratio, roa, age, fixed asset ratio, cash flow, G-Index, and E-Index as control variables. All regressions include industry dummies. F-statistics (IV) represents statistics from an F-test of whether instrumental variables are jointly zero. t-statistics are reported in parentheses, by using standard errors adjusted for heteroscedasticity and clustered at the firm level. *, **, *** indicate statistical significance at the $10 \%, 5 \%$, and $1 \%$ level, respectively.

\begin{tabular}{|c|c|c|c|c|c|c|c|c|c|}
\hline & (1) Tobin'Q & (2) Tobin'Q & (3) Tobin'Q & (4) $\mathrm{CI}$ & (5) CI & (6) $\mathrm{CI}$ & (7) EM & (8) EM & (9) EM \\
\hline \multirow{2}{*}{$\overline{\text { IV (RPI_SYI(- }-i) \text { ) }}$} & 0.5258 & 1.3428 & 2.7328 & -0.1719 & -0.1340 & -0.1385 & -0.0100 & -0.0255 & -0.0255 \\
\hline & $(10.70)^{* * *}$ & $(4.12)^{* * *}$ & $(4.65)^{* * *}$ & $(6.76)^{* * *}$ & $(3.77)^{* * *}$ & $(3.67)^{* * *}$ & $(8.06)^{* * *}$ & $(7.08) * * *$ & $(8.24)^{* * *}$ \\
\hline \multirow[t]{2}{*}{ SIZE } & -0.5712 & -0.8498 & -1.6940 & 0.1422 & 0.0796 & 0.0803 & 0.0054 & 0.0158 & 0.0164 \\
\hline & $(14.36)^{* * *}$ & $(4.36)^{* * *}$ & $(4.85)^{* * *}$ & $(4.84)^{* * *}$ & $(2.94)^{* * *}$ & $(2.74)^{* * *}$ & $(3.39)^{* * *}$ & $(5.43)^{* * *}$ & $(6.50)^{* * *}$ \\
\hline \multirow[t]{2}{*}{$\mathrm{BM}$} & & & & -0.0590 & -0.0793 & -0.1092 & -0.0040 & 0.0007 & 0.0004 \\
\hline & & & & $(4.42)^{* * *}$ & $(3.91)^{* * *}$ & $(4.78) * * *$ & $(3.70)^{* * *}$ & $(0.37)$ & $(0.42)$ \\
\hline \multirow[t]{2}{*}{$\mathrm{ROA}$} & -0.9052 & 1.7695 & 0.9729 & 0.1203 & 0.3784 & 0.3642 & -0.0092 & -0.0081 & -0.0070 \\
\hline & $(7.92)^{* * *}$ & $(2.79) * * *$ & $(1.26)$ & $(0.93)$ & $(1.97)^{* *}$ & $(1.76)^{*}$ & $(18.27)^{* * *}$ & $(5.64)^{* * *}$ & $(5.58) * * *$ \\
\hline \multirow{2}{*}{ AGE } & 0.0505 & 0.1835 & 0.4984 & & & & -0.0118 & -0.1397 & -0.1110 \\
\hline & $(2.10)^{* *}$ & (1.61) & $(2.21)^{* *}$ & & & & $(3.35)^{* * *}$ & $(3.89)^{* * *}$ & $(4.47)^{* * *}$ \\
\hline \multirow[t]{2}{*}{ R\&D/Sales } & 0.0016 & 0.0155 & 0.0049 & & & & & & \\
\hline & $(1.03)$ & $(0.84)$ & $(0.45)$ & & & & & & \\
\hline \multirow[t]{2}{*}{ IOR } & -1.0411 & -2.6511 & -4.1696 & & & & & & \\
\hline & $(5.17)^{* * *}$ & $(5.18)^{* * *}$ & $(5.60)^{* * *}$ & & & & & & \\
\hline \multirow[t]{2}{*}{ FixedAsset } & & & & -0.1779 & -0.0558 & -0.0485 & & & \\
\hline & & & & $(4.32)^{* * *}$ & $(1.46)$ & $(1.15)$ & & & \\
\hline \multirow[t]{2}{*}{ CashFlow } & & & & -0.0023 & -0.5029 & -0.4680 & 0.0091 & 0.1313 & 0.0809 \\
\hline & & & & $(0.02)$ & $(1.69)^{*}$ & $(1.42)$ & $(2.48)^{* *}$ & $(3.58)^{* * *}$ & $(3.11)^{* * *}$ \\
\hline \multirow[t]{2}{*}{ Leverage } & & & & -0.3168 & -0.1248 & -0.1393 & & & \\
\hline & & & & $(6.77)^{* * *}$ & $(2.37)^{* *}$ & $(2.42)^{* *}$ & & & \\
\hline \multirow[t]{2}{*}{ SaleGrowth } & & & & 0.1139 & 0.1745 & 0.1716 & & & \\
\hline & & & & $(3.85)^{* * *}$ & $(4.73) * * *$ & $(4.44)^{* * *}$ & & & \\
\hline \multirow[t]{2}{*}{ Tobin's Q } & & & & 0.0170 & 0.0096 & 0.0051 & & & \\
\hline & & & & $(2.64)^{* * *}$ & $(1.12)$ & $(0.59)$ & & & \\
\hline \multirow[t]{2}{*}{ Capx } & & & & & & & -0.0033 & 0.0140 & 0.0330 \\
\hline & & & & & & & $(1.49)$ & $(0.97)$ & $(2.76)^{* * *}$ \\
\hline \multirow[t]{2}{*}{ G-Index } & & -0.0539 & & & 0.0022 & & & 0.0011 & \\
\hline & & $(2.49)^{* *}$ & & & $(0.96)$ & & & $(3.02)^{* * *}$ & \\
\hline \multirow[t]{2}{*}{ E-Index } & & & -0.1148 & & & 0.0099 & & & 0.0000 \\
\hline & & & $(1.55)$ & & & $(1.97)^{* *}$ & & & $(0.05)$ \\
\hline \multirow[t]{2}{*}{ RPI_SYI(-i) } & 0.0431 & 0.0222 & 0.0147 & 0.0403 & 0.0217 & 0.0227 & 0.0444 & 0.0151 & 0.0189 \\
\hline & $(7.34)^{* * *}$ & $(2.70)^{* * *}$ & $(1.78)^{*}$ & $(7.23)^{* * *}$ & $(3.27)^{* * *}$ & $(3.32)^{* * *}$ & $(7.78)^{* * *}$ & $(2.08)^{* *}$ & $(2.93)^{* * *}$ \\
\hline Ind Dummies & Y & $\mathrm{Y}$ & $\mathrm{Y}$ & Y & $\mathrm{Y}$ & $\mathrm{Y}$ & $\mathrm{Y}$ & $\mathrm{Y}$ & $\mathrm{Y}$ \\
\hline F-statistics (IV) & 24.26 & 4.29 & 3.67 & 43.21 & 18.24 & 19.92 & 17.19 & 5.27 & 7.54 \\
\hline Prob $>F(I V)$ & 0.0000 & 0.0000 & 0.0000 & 0.0000 & 0.0000 & 0.0000 & 0.0000 & 0.0000 & 0.0000 \\
\hline Obs & 81264 & 6757 & 6292 & 57424 & 12363 & 11192 & 80692 & 12267 & 14473 \\
\hline $\mathrm{R} 2$ & $53.33 \%$ & $68.82 \%$ & $38.14 \%$ & $0.63 \%$ & $0.29 \%$ & $0.40 \%$ & $49.88 \%$ & $39.91 \%$ & $41.81 \%$ \\
\hline
\end{tabular}


Table 14. Alternative Instrumental variable regressions for RPI and Subsequent Tobin's Q, CI, and EM This table reports the second stage's results of two-stage-least-square regression results of the impact of RPI on subsequent firm value, abnormal capital investments, and earnings management. We utilize the mean of RPI of firms whose market capitalization is below the mean in the same state, same industry, and same year, excluding firm i's own RPI, as the IV for RPI, denoted as RPI_SYI $(-i)_{b}$. We use firms with their market capitalization above median. In model (1), (2), and (3), we report the results for the subsequent Tobin's Q, abnormal capital investment, and earnings management respectively. In the first stage, we regress the RPI on RPI_SYI $(-i)_{b}$ and other control variables, including firm size, book-to-market ratio, return on assets, firm's age, R\&D expenditure scaled by sales, institutional ownership ratio, fixed asset ratio, cash flow, leverage ratio, the growth of sales, and firm value. All regressions control for industry- and year-fixed effects. Robust errors are clustered at the firm level and adjusted for heteroscedasticity. We do not report the first stage's results for brevity. In the second stage, the variable of interest is the estimated value of RPI, IV(RPI_SYI $(-i)_{b}$ ). The dependent variables in model (1), we include firm size (log of total asset), book-to-market ratio, ROA, age, $\mathrm{R} \& \mathrm{D}$ expenditures, institutional ownership ratio as control variables. In model (2), we include firm size (log of market capitalization), book-to-market ratio, ROA, fixed asset ratio, cash flow, leverage ratio, sales growth, Tobin's Q as control variables. In model (3), we include firm size (log of market capitalization), book-to-market ratio, ROA, age, fixed asset ratio, cash flow as control variables. All regressions include industry dummies. F-statistics (IV) represents statistics from an F-test of whether instrumental variables are jointly zero. t-statistics are reported in parentheses, by using standard errors adjusted for heteroscedasticity and clustered at the firm level. ${ }^{*}, * * * *$ indicate statistical significance at the $10 \%, 5 \%$, and $1 \%$ level, respectively.

\begin{tabular}{|c|c|c|c|}
\hline & (1) Tobin's Q & (2) CI & (3) EM \\
\hline \multirow{2}{*}{$\overline{\mathrm{IV}\left(\mathrm{RPI} S \mathrm{SYI}(-i)_{b}\right)}$} & 0.4386 & -0.2897 & -0.0250 \\
\hline & $(7.98)^{* * *}$ & $(9.08)^{* * *}$ & $(10.72)^{* * *}$ \\
\hline \multirow[t]{2}{*}{ SIZE } & -0.3445 & 0.2153 & 0.0197 \\
\hline & $(8.69)^{* * *}$ & $(7.24)^{* * *}$ & $(8.00)^{* * *}$ \\
\hline \multirow[t]{2}{*}{ BM } & & -0.0811 & -0.0031 \\
\hline & & $(4.14)^{* * *}$ & $(1.67)^{*}$ \\
\hline \multirow[t]{2}{*}{ ROA } & -0.0287 & 0.3191 & -0.0074 \\
\hline & $(1.41)$ & $(1.61)$ & $(1.09)$ \\
\hline \multirow[t]{2}{*}{ AGE } & 2.8224 & & -0.0088 \\
\hline & $(12.86)^{* * *}$ & & $(11.62)^{* * *}$ \\
\hline \multirow[t]{2}{*}{ R\&D/Sales } & $\begin{array}{r}0.0113 \\
(766) * * *\end{array}$ & & \\
\hline & $\begin{array}{r}(7.66)^{* * *} \\
-0.7355\end{array}$ & & \\
\hline IOR & $(4.66)^{* * *}$ & & \\
\hline \multirow[t]{2}{*}{ FixedAsset } & & -0.1886 & \\
\hline & & $(4.13)^{* * *}$ & \\
\hline \multirow[t]{2}{*}{ CashFlow } & & -0.0097 & 0.0076 \\
\hline & & $(0.04)$ & $(1.11)$ \\
\hline \multirow[t]{2}{*}{ Leverage } & & -0.2459 & \\
\hline & & $(5.37)^{* * *}$ & \\
\hline \multirow[t]{2}{*}{ SaleGrowth } & & 0.1239 & \\
\hline & & $(5.38)^{* * *}$ & \\
\hline \multirow[t]{2}{*}{ Tobin's Q } & & 0.0008 & \\
\hline & & $(0.12)$ & \\
\hline \multirow[t]{2}{*}{ Capx } & & & 0.0005 \\
\hline & & & $(0.20)$ \\
\hline \multirow[t]{2}{*}{ RPI_SYI(-i) } & 0.0206 & 0.0262 & 0.0227 \\
\hline & $(3.82)^{* * *}$ & $(5.18)^{* * *}$ & $(4.44)^{* * *}$ \\
\hline Ind Dummies & $\mathrm{Y}$ & Y & $\mathrm{Y}$ \\
\hline F-statistics (IV) & 19.27 & 22.3 & 14.24 \\
\hline Prob>F(IV) & 0.0000 & 0.0000 & 0.0000 \\
\hline Obs & 38022 & 28189 & 37759 \\
\hline $\mathrm{R} 2$ & 0.1908 & 0.009 & 0.0542 \\
\hline
\end{tabular}


Table 15. Robust regressions for RPI and Subsequent Tobin's Q, CI, and EM

This table reports the robust regressions for RPI and subsequent firm value, abnormal capital investments, and earnings management. In model (1), (4), and (7), we control for both year and firm fixed effect, and cluster the robust errors at the firm level and adjusted for heteroscedasticity. In model (2), (5), and (8), we control for both year and firm fixed effect, and cluster the robust errors at the industry level and adjusted for heteroscedasticity. In model (3), (6), and (9), we control for both year and industry fixed effect, and cluster the robust errors at the firm level and adjusted for heteroscedasticity. We include other main control variables, namely firm size, book-to-market ratio, return on assets, firm's age, R\&D expenditure scaled by sales, institutional ownership ratio, fixed asset ratio, cash flow, leverage ratio, the growth of sales, and firm value. $t$-values are in parentheses. $*, * *, * * *$ indicate statistical significance at the $10 \%, 5 \%$, and $1 \%$ level, respectively.

\begin{tabular}{|c|c|c|c|c|c|c|c|c|c|}
\hline & (1) Tobin'Q ( & Tobin'Q & 3) Tobin'Q & (4) $\mathrm{CI}$ & (5) $\mathrm{CI}$ & (6) $\mathrm{CI}$ & (7) EM & (8) EM & (9) EM \\
\hline RPI & 0.0592 & 0.0592 & 0.3271 & -0.0551 & -0.0551 & -0.0432 & -0.0020 & -0.0020 & -0.0015 \\
\hline & $(4.48)^{* * *}$ & $(4.55)^{* * *}$ & $(22.42)^{* * *}$ & $(3.35)^{* * *}$ & $(3.20)^{* * *}$ & $(5.35)^{* * *}$ & $(5.99)^{* * *}$ & $(4.47)^{* * *}$ & $(4.28)^{* * *}$ \\
\hline SIZE & -0.7296 & -0.7296 & -0.4259 & -0.0350 & -0.0350 & -0.0070 & -0.0038 & -0.0038 & -0.0049 \\
\hline & $(17.68)^{* * *}$ & $(6.85)^{* * *}$ & $(23.56)^{* * *}$ & $(2.28)^{* *}$ & $(1.72)^{*}$ & $(0.93)$ & $(5.71)^{* * *}$ & $(4.40)^{* * *}$ & $(9.80)^{* * *}$ \\
\hline $\mathrm{BM}$ & & & & -0.1323 & -0.1323 & -0.0668 & -0.0042 & -0.0042 & -0.0060 \\
\hline & & & & $(9.51)^{* * *}$ & $(7.32)^{* * *}$ & $(6.09)^{* * *}$ & $(3.47)^{* * *}$ & $(3.02)^{* * *}$ & $(4.20)^{* * *}$ \\
\hline ROA & -0.0413 & -0.0413 & -0.8085 & 0.1082 & 0.1082 & 0.2107 & -0.0026 & -0.0026 & -0.0079 \\
\hline & $(0.34)$ & $(0.29)$ & $(6.19)^{* * *}$ & $(0.86)$ & $(0.85)$ & (1.19) & $(1.13)$ & $(1.10)$ & $(3.39)^{* * *}$ \\
\hline $\mathrm{AGE}$ & 0.0087 & 0.0087 & 0.0033 & & & & 0.0004 & 0.0004 & -0.0004 \\
\hline & $(0.95)$ & $(1.13)$ & $(2.65)^{* * *}$ & & & & $(1.20)$ & $(1.46)$ & $(6.84)^{* * *}$ \\
\hline R\&D/Sales & 0.0007 & 0.0007 & 0.0022 & & & & & & \\
\hline & $(0.29)$ & $(0.94)$ & $(1.33)$ & & & & & & \\
\hline IOR & 0.5609 & 0.5609 & -0.1618 & & & & & & \\
\hline & $(5.22)^{* * *}$ & $(3.85)^{* * *}$ & $(2.15)^{* *}$ & & & & & & \\
\hline Insiderownership & 0.0502 & 0.0502 & 0.0585 & & & & & & \\
\hline & $(2.36)^{* *}$ & $(2.12)^{* *}$ & $(2.41)^{* *}$ & & & & & & \\
\hline Insiderownership ${ }^{2}$ & -0.0009 & -0.0009 & -0.0012 & & & & & & \\
\hline & $(2.50)^{* *}$ & $(2.18)^{* *}$ & $(3.06)^{* * *}$ & & & & & & \\
\hline FixedAsset & & & & -0.0792 & -0.0792 & -0.0529 & & & \\
\hline & & & & $(2.74)^{* * *}$ & $(2.88)^{* * *}$ & $(2.11)^{* *}$ & & & \\
\hline CashFlow & & & & 0.2816 & 0.2816 & -0.0772 & 0.0022 & 0.0022 & 0.0064 \\
\hline & & & & $(1.85)^{*}$ & $(1.90)^{*}$ & $(0.42)$ & $(1.04)$ & $(1.02)$ & $(2.31)^{* *}$ \\
\hline Leverage & & & & -0.8299 & -0.8299 & -0.3054 & & & \\
\hline & & & & $(10.09)^{* * *}$ & $(9.63)^{* * *}$ & $(5.98)^{* * *}$ & & & \\
\hline SaleGrowth & & & & 0.1228 & 0.1228 & 0.1489 & & & \\
\hline & & & & $(2.45)^{* *}$ & $(2.44)^{* *}$ & $(3.39)^{* * *}$ & & & \\
\hline Tobin's Q & & & & 0.0281 & 0.0281 & 0.0285 & & & \\
\hline & & & & $(3.34)^{* * *}$ & $(3.09)^{* * *}$ & $(3.69)^{* * *}$ & & & \\
\hline Capx & & & & & & & -0.0003 & -0.0003 & -0.0003 \\
\hline & & & & & & & $(0.37)$ & $(0.35)$ & $(0.41)$ \\
\hline Year Dummies & $\mathrm{Y}$ & $\mathrm{Y}$ & $\mathrm{Y}$ & $\mathrm{Y}$ & $\mathrm{Y}$ & $\mathrm{Y}$ & $\mathrm{Y}$ & Y & $\mathrm{Y}$ \\
\hline Industry Dummies & $\mathrm{X}$ & $\mathrm{X}$ & $\mathrm{Y}$ & $\mathrm{X}$ & $\mathrm{X}$ & $\mathrm{Y}$ & $\mathrm{X}$ & $\mathrm{X}$ & $\mathrm{Y}$ \\
\hline Firm Dummies & $\mathrm{Y}$ & $\mathrm{Y}$ & $\mathrm{X}$ & $\mathrm{Y}$ & $\mathrm{Y}$ & $\mathrm{X}$ & $\mathrm{Y}$ & $\mathrm{Y}$ & $\mathrm{X}$ \\
\hline Firm Cluster & $\mathrm{Y}$ & $\mathrm{X}$ & $\mathrm{Y}$ & $\mathrm{Y}$ & $\mathrm{X}$ & $\mathrm{Y}$ & Y & $\mathrm{X}$ & $\mathrm{Y}$ \\
\hline Industry Cluster & $\mathrm{X}$ & $\mathrm{Y}$ & $\mathrm{X}$ & $\mathrm{X}$ & $\mathrm{Y}$ & $\mathrm{X}$ & $\mathrm{X}$ & Y & $\mathrm{X}$ \\
\hline Obs & 63240 & 63240 & 63240 & 66756 & 66756 & 66756 & 100365 & 100365 & 100365 \\
\hline $\mathrm{R} 2$ & 0.5035 & 0.5035 & 0.1668 & 0.2384 & 0.2384 & 0.0157 & 0.3287 & 0.3287 & 0.0968 \\
\hline
\end{tabular}

